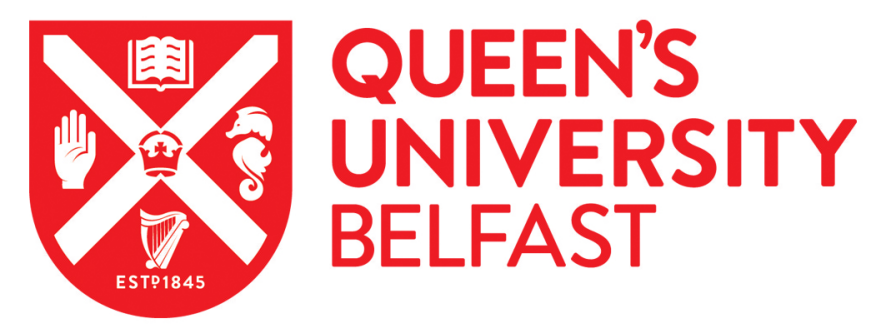

\title{
A regional soil and river sediment geochemical study in Baoshan area, Yunnan province, southwest China
}

Zhang, L., McKinley, J., Cooper, M., Peng, M., Wang, Q., Song, Y., \& Cheng, H. (2020). A regional soil and river sediment geochemical study in Baoshan area, Yunnan province, southwest China. Journal of Geochemical Exploration, [106557].

Published in:

Journal of Geochemical Exploration

Document Version:

Peer reviewed version

Queen's University Belfast - Research Portal:

Link to publication record in Queen's University Belfast Research Portal

Publisher rights

() 2020 Published by Elsevier B.V.

This manuscript is distributed under a Creative Commons Attribution-NonCommercial-NoDerivs License

(https://creativecommons.org/licenses/by-nc-nd/4.0/), which permits distribution and reproduction for non-commercial purposes, provided the author and source are cited.

\section{General rights}

Copyright for the publications made accessible via the Queen's University Belfast Research Portal is retained by the author(s) and / or other copyright owners and it is a condition of accessing these publications that users recognise and abide by the legal requirements associated with these rights.

Take down policy

The Research Portal is Queen's institutional repository that provides access to Queen's research output. Every effort has been made to ensure that content in the Research Portal does not infringe any person's rights, or applicable UK laws. If you discover content in the Research Portal that you believe breaches copyright or violates any law, please contact openaccess@qub.ac.uk. 


\section{A regional soil and river sediment geochemical study in Baoshan area, Yunnan province, southwest China}

Li Zhang, ${ }^{a, b, c, d}$, Jennifer M. McKinley ${ }^{d}$, Mark Cooper ${ }^{e}$, Min Peng, ${ }^{a, b, c}$, Qiaolin Wang, ${ }^{\text {a,c }}$ Yuntao Song ${ }^{\text {a,c }}$, Hangxin Cheng, ${ }^{\text {a, } *}$

a. Key Laboratory of Geochemical Cycling of Carbon and Mercury in the Earth's Critical Zone, Institute of Geophysical \& Geochemical Exploration, Chinese Academy of Geological Sciences, Langfang 065000, China

b. China University of Geosciences, Beijing 100083, China

c. Research Center of Geochemical Survey and Assessment on Land Quality, China Geological Survey, Langfang 065000, China

d. School of Natural and Built Environment, Queen's University Belfast, Belfast BT7 1NN, UK

e. Geological Survey of Northern Ireland, Belfast, BT4 3SB, UK

*corresponding author at: Key Laboratory of Geochemical Cycling of Carbon and Mercury in the Earth's Critical Zone, Institute of Geophysical \& Geochemical Exploration, Chinese Academy of Geological Sciences, Langfang 065000, China. Tel. : +86 3162267630; fax: +86316 2014156. E-mail address: chenghangxin@igge.cn (H. Cheng)

Highlights :

* Geochemical status of surface environments in the Baoshan area have been revealed

* Chemical elements in study area are mainly controlled by geology and geomorphology

* Land use types also show its contributions to $\mathrm{pH}$ in soil

* Agricultural fertilization caused enrichment of the nutrient elements in surface soil

* Mining activities are the main reason for PTMs enrichment in surface soil near mine

\section{Abstract}

This study aims to better understand, at a regional scale, the concentration and distribution of selected chemical elements in surface environments and the influence of natural factors (geological background, geomorphology) and anthropogenic factors (mining activities, land-use, agricultural 
fertilization) on their distribution in the Baoshan area, Yunnan province, southwest China. Mineral resources (such as copper, lead, zinc, mercury, gold, silver) and carbonate and basalt parent materials in this area often lead to elevated potentially toxic metals (PTMs), which are widely distributed where mining activities have rapidly developed since last 20-30 years. This study makes use of 1574 surface soil data and 425 deep soil data from the National Geochemistry Survey of Land Quality project (NGSLQ), and 1585 archived river sediment data which were collected and analyzed for the Regional Geochemistry-National Reconnaissance program (RGNR). These data, once log-ratio (clr) transformed have been studied by compositional data analysis (CoDA), principle components analysis (PCA) and spatial analysis. In the Baoshan area, the concentration of elements As, B, (Br), $\mathrm{Co}, \mathrm{Cr}, \mathrm{Cu}, \mathrm{Hg},(\mathrm{I}), \mathrm{Mn},(\mathrm{N}), \mathrm{Ni}, \mathrm{Sb},(\mathrm{Sc}),(\mathrm{Se}), \mathrm{V}, \mathrm{Fe}_{2} \mathrm{O}_{3 \mathrm{Total}}$ and $\mathrm{C}_{\text {Organic }}$ are enriched compared to the China Soil Geochemical Baselines program (CGB) and RGNR data sets; while elements Sr and $\mathrm{Na}_{2} \mathrm{O}$ are depleted compared to CGB and RGNR data sets. Influencing factors on surface soil, deep soil and river sediment composition of the study area are revealed. The distribution of most elements in surface soil, deep soil and river sediment are influenced by natural factors such that: $\mathrm{Co}, \mathrm{Cr}, \mathrm{Cu}$, $\mathrm{Ni}, \mathrm{Sc}, \mathrm{Ti}, \mathrm{V}, \mathrm{Fe}_{2} \mathrm{O}_{3}$ Total and $\mathrm{MgO}$ are controlled by the distribution of basic igneous rocks; $\mathrm{Ca}, \mathrm{Mg}$, $\mathrm{Sr}$ and $\mathrm{pH}$ are controlled by the distribution of carbonate rocks and basic igneous rocks; $\mathrm{As}, \mathrm{Hg}, \mathrm{Sb}$, $(\mathrm{Ag}), \mathrm{Cd}, \mathrm{Pb}$ and $\mathrm{Zn}$ are controlled by mineralization; and other elements normally controlled by the distribution of clastic rocks and acid-intermediate rocks; while the organic matter such as $\mathrm{Br}, \mathrm{N}$, (P), $\mathrm{S}, \mathrm{C}_{\text {Orgonic }}$ and $\mathrm{C}_{\text {Total }}$ in soil data set are controlled by geomorphic (altitude and temperature). Anthropogenic factors are also recognized in the soil data set. For example: high $\mathrm{pH}$ values in paddy land and grassland, and low $\mathrm{pH}$ values in forested land, garden plot and dry cultivated land; in agricultural area fertilization has caused enrichment of the nutrient elements $\left(\mathrm{C}_{\text {Orgonic, }} \mathrm{C}_{\text {Total }}, \mathrm{N}, \mathrm{P}\right.$ etc.,) in surface soil; while in areas of mining, surface soils are contaminated by PTMs (incl. Hg, $\mathrm{As}, \mathrm{Sb}, \mathrm{Cu}, \mathrm{Pb}, \mathrm{Zn}$ and $\mathrm{Cd}$ ) near the mine area.

Keywords: NGSLQ, PTMs, CoDA, Principal component analysis, Enrichment factor, Baoshan 


\section{Introduction}

\subsection{Overview}

Since 1999, the National Geochemistry Survey of Land Quality project (NGSLQ), has been carried out in agriculturally and industrially developed regions of China by the China Geological Survey (CGS). Prior to 2012 the NGSLQ was called the National Multi-Purpose Regional Geochemical Survey (NMPRGS). The purpose of the project is to provide modern, higher density, more sensitive, more systematic and multi-medium geochemical data for supporting science-based decisions related to assessing land resources, protecting the surface environment, and improving the efficiency of agriculture (Li et al 2014a). More than 200 million $\mathrm{km}^{2}$ of land has been surveyed at a scale of 1:250000, mainly on the plains of eastern and central China and in some parts of southwest and northwest of China. A large volume of geochemical data of soil sample have been obtained, include total concentration of 54 elements and indictors (Ag, As, Au, B, Ba, Be, Bi, Br, Cd, Ce, Cl, Co, Cr, Cu, F, Ga, Ge, Hg, I, La, Li, Mn, Mo, N, Nb, Ni, P, Pb, Rb, S, Sb, Sc, Se, Sn, Sr, Th, Ti, Tl, $\mathrm{U}, \mathrm{V}, \mathrm{W}, \mathrm{Y}, \mathrm{Zn}, \mathrm{Zr}, \mathrm{SiO}_{2}, \mathrm{Al}_{2} \mathrm{O}_{3}, \mathrm{Fe}_{2} \mathrm{O}_{3}$ Total, $\mathrm{MgO}, \mathrm{CaO}, \mathrm{Na}_{2} \mathrm{O}, \mathrm{K}_{2} \mathrm{O}, \mathrm{C}_{\text {Total }}, \mathrm{C}_{\text {Orgonic }}$ and $\mathrm{pH}$ ). Several atlases and papers have been published since this program was initiated, typically by the volume Exploring China: Environment and Resources published in the Journal of Geochemical Exploration in 2014 (Cheng et al., 2014a).

Soil and cultivatable land are the basis for food production and play an essential role in national food security. With competing pressures between population, resources and the environment, soil quality has become a major concern globally (Cicchella et al., 2008; Kelepertzis et al., 2013; Li et al., 2010; Li et al., 2014b; Luo et al., 2012; Zhang et al., 2013). The external morphology and internal characteristics of soil are determined by parent material, biology, climate, topography, time, and human activities (Dokuchaev, 1967; Jenny, 1941). The concentration and distribution of elements in soil are also controlled by those factors. The enrichment of chemical elements especially potentially toxic metals (PTMs) in soil by human activities (industrial and mining activities, agricultural fertilization and irrigation and urban living pollutants, etc.) have become recognized by public authorities and are well researched by scientists (Addo et al., 2012; Chiu et al., 2016; Hamzeh 
et al., 2011; Luo et al., 2012; McGrath and Tunney, 2010). While, the enrichment and deficit of elements in soil due to the geological background are mainly caused by the weathering process of parent materials. The critical role of the geological background in contributing to elevated chemical elements in soil is reviewed by a significant body of research in this field (e.g. Antibachi et al., 2012; Becquer et al., 2006; Bompoti et al., 2015; Bonifacio et al., 2010; Kelepertzis et al., 2013; Tashakor et al., 2014).

The geochemical mapping provides a more detailed information about the spatial variability of chemical components for environmental studies, particularly in discriminating potential sources of contribution (either anthropogenic and geogenic) in global, continent and regional scale (Albanese et al., 2007; Darnley and Garrett, 1990; Darnley et al., 1995; Gałuszka, 2007; Plant et al., 2001; Qu et al., 2018, 2019; Reimann and Caritat, 2017, 2005; Yuan et al., 2013; Sahoo et al., 2019a, 2019b, 2020; Salomão et al., 2019). The presences of mineral resources (such as copper, lead, zinc, mercury, gold, silver) and carbonate and basalt parent materials often lead to elevated PTMs in soil (Barsby et al., 2012; Cabral Pinto et al., 2017; Cheng, 2016; Cox et al., 2017; Goldhaber et al., 2009; Tolosana-Delgado and McKinley, 2016; Wang et al., 2015; Zhang et al., 2002). This can be seen in soils in the Baoshan area, Yunnan province, southwest China, where mining activities have developed rapidly in the past two to three decades. The Baoshan area $\left(6220 \mathrm{~km}^{2}\right)$ was surveyed in 2016 at a scale of 1: 250000 to better understand the regional geochemical status and the influence of natural factors (geological background, geomorphology), and anthropogenic activities (mining activities, land-use, agricultural fertilization) on the distribution of selected elements in surface environments. A total of 1585 archived river sediment samples, which were collected and analyzed as part of the Regional Geochemistry-National Reconnaissance program (RGNR) in China, have been used as the dataset for this study, and it has not been published elsewhere.

Geochemical data do not change independently and freely, but must accommodate each other within the constant sum constraint of the closed composition, which was identified to induce spurious behavior on the correlation coefficient (Chayes, 1960), called negative bias (the negative correlation coefficients between major components) and the spurious correlation effect (the correlation between two components unpredictably changes when considering different subcompositions) (Tolosana-Delgado and McKinley, 2016). Aitchison (1981, 1982, 1986) and Egozcue et al. (2003) proposed log-ratio transformations, in the form of the pairwise log-ratio transformation 
112 (pwlr), the additive log-ratio transformation (alr) and the centred log-ratio transformation (clr), and

113 isometric log-ratio (ilr) transformation to make the classical (Euclidean) statistical methods 114 applicable to compositional data. The field of compositional data analysis (CoDA) has been widely 115 developed since Aitchison's work to solve the limitations on geochemical data (e.g. Boogaart and 116 Tolosana-Delgado, 2013; Egozcue et al., 2003; Pawlowsky-Glahn and Buccianti, 2011; Pawlowsky-

117 Glahn and Egozcue, 2001). There are a series of mathematical tools for extracting meaningful results 118 from compositional data, yet none of these transformation methods is inherently better than the other. 119 McKinley et al. (2016) proposed two approaches (a) knowledge-driven log-ratios, chosen to 120 highlight certain geochemical relations or to filter known artefacts (e.g. dilution with $\mathrm{SiO}_{2}$ or 121 volatiles); (b) log-contrasts, that employ suitable statistical methods (such as classification 122 techniques, regression analysis, principal component analysis, and clustering of variables) with log123 ratio transformed data to extract potentially interesting geochemical summaries to solve the 124 limitations on geochemical data.

125 This study uses CoDA methods and focuses on 1) the concentration and distribution of selected 126 chemical elements at a regional scale in soil and river sediments of the Baoshan area; 2) the 127 influence of natural factors (geological background, geomorphology) and anthropogenic factors 128 (mining activities, land-use, agricultural fertilization) on the pattern of chemical concentrations in 129 soil and river sediments; 3 ) the main controlling factors on the occurrence of PTMs (As, $\mathrm{Cd}, \mathrm{Cr}, \mathrm{Cu}$, $130 \mathrm{Hg}, \mathrm{Ni}, \mathrm{Pb}, \mathrm{Zn}, \mathrm{Ag}$, etc.).

$131 \quad \mathbf{1 . 2}$ Study area

Baoshan is located in the western Yunnan province with complex topography, at low latitude and with moderate elevation. Baoshan has a mild subtropical highland climate, with short, mild, dry winters, and warm, rainy summers. Contour maps of altitude, and average surface soil temperature and rainfall are shown in Fig.1. Variation of average temperature are directly related to altitude. Rainfall is greatest in the western and southern parts of the study area. The main types of land-use in the study area are: forest land, dry cultivated land, paddy land, grassland, garden plot, with few water areas and other types (including: residential quarter and industrial and mining land, and unused land). The simplified land-use map is shown in Fig.2a. 
Geologically, the study area is located in the Sanjiang area of Yunnan province, which consists of Tengchong, Baoshan, and Lanping-Simao blocks (Fig.2b, c; Dong et al., 2013; Li et al., 2015;

142 Wang et al., 2010). The rock types of the Baoshan Block mainly consist of Paleozoic to Mesozoic 143 sedimentary rocks, and Early Paleozoic and Late Mesozoic-Early Cenozoic magmatic rocks (Dong 144 et al., 2013; Wang et al., 2013). Exposed within the study area are mainly Quaternary to Precambrian stratum and sparse granite and diabase intrusions. Basalt occurs in the Carboniferous and Jurassic rock sequences that are mainly distributed in the western and northeast part of the study area. The major rock types of the all strata in each geological age are shown in Fig. 2d. Mineral deposits, which are often associated with PTMs pollution in soil, are widely distributed across the study area and include copper-lead-zinc and mercury workings (Fig. 2d).

\section{Methodology}

\subsection{Sample collection and preparation}

This study uses soil samples collected in 2016 as part of the NGSLQ project, and supplemented archived river sediment samples collected during the RGNR program. A systematic, regular grid sampling design was applied for both the NGSLQ and RGNR (CGS, 2005, 2014; Xie et al., 2008; Xie and Cheng, 2014).

Surface soil at 0-20 cm depth were collected at a density of 1 sample/ $/ \mathrm{km}^{2}$ with one main sample and 3-5 sub-holes within 50m of the sampling site. Deep soil at 150-180 cm depth, or soil from C horizon if soil depth is less than $150 \mathrm{~cm}$, were taken at a density of $1 \mathrm{sample} / 4 \mathrm{~km}^{2}$ in the study area. Among surface soil and deep soil samples, about $2 \%-3 \%$ of the sampling sites were re-sampled to assess sampling variation. Each sample site was selected from the most representative land-use types within the most common soil types in the sampling cell. In order to reduce the analytical cost, samples from $4 \mathrm{~km}^{2}$ for surface soil and $16 \mathrm{~km}^{2}$ for deep soil were composited (Fig. S2, supplementary file). The sample collection and preparation details are provided by Li et al., (2014a) and supplementary file. The soil samples were disaggregated using a wooden hammer during airdrying and sieved with -20 mesh screen $(<0.84 \mathrm{~mm})$, once dried they were further processed to 200 mesh $(<0.074 \mathrm{~mm})$ for analysis. 
Detailed sampling methods and prepare processes for river sediments are described in previous papers (Xie et al., 2008, Xie and Cheng, 2014). Briefly, river sediment samples were collected at an average density of 1 sample $\mathrm{km}^{2}$ from first-order streams, and all samples within a $4 \mathrm{~km}^{2}$ grid were composited to obtain a sample for chemical analysis. The river sediment samples were sampled with -60 mesh $(<0.42 \mathrm{~mm})$ in the field and were further processed to -200 mesh $(<0.074 \mathrm{~mm})$ for analysis.

All the sampling positions were pinpointed by Global Positioning System (GPS). The central locations of composited surface soil, deep soil and river sediments are showed in Fig. S2 (supplementary file), include a total of 1574 surface soil data, 425 deep soil data, and 1585 river sediment data.

\subsection{Chemical analysis and quality control}

The total content of 54 elements and indictors (Ag, As, $\mathrm{Au}, \mathrm{B}, \mathrm{Ba}, \mathrm{Be}, \mathrm{Bi}, \mathrm{Br}, \mathrm{Cd}, \mathrm{Ce}, \mathrm{Cl}, \mathrm{Co}$, Cr, Cu, F, Ga, Ge, Hg, I, La, Li, Mn, Mo, N, Nb, Ni, P, Pb, Rb, S, Sb, Sc, Se, Sn, Sr, Th, Ti, Tl, U, V, W, Y, Zn, Zr, $\mathrm{SiO}_{2}, \mathrm{Al}_{2} \mathrm{O}_{3}, \mathrm{Fe}_{2} \mathrm{O}_{3 \text { Total }}, \mathrm{MgO}, \mathrm{CaO}, \mathrm{Na}_{2} \mathrm{O}, \mathrm{K}_{2} \mathrm{O}, \mathrm{C}_{\text {Total }}$, Corgonic and pH) of all soil samples were determined in the Central Analytical Laboratory of the Institute of Geophysical \& Geochemical Exploration (IGGE). The analytical methods and detection limits are listed in Table S 1 (supplementary file). The detailed analytical procedures are reviewed by Zheng et al., (2005).

Internal and external controls were implemented during the routine analysis to check accuracy and precision. Briefly, certified reference materials (CRMs) and blind reference materials (BRMs) were analyzed with samples simultaneously to assess the accuracy and precision of sample analysis. The detailed description can be seen in Li et al., (2014 a) and supplementary file. The requirements of accuracy and precision were listed in Table S2 and Table S3 (supplementary file), while for pH, the relative deviation (RD) between sample and CRMs should be satisfied with $|\Delta \mathrm{pH}| \leq 0.1$. The accuracies and precisions of all elements in all samples are satisfied with the analytical requirements developed in the NMPRGS/ NGSLQ project (CGS, 2005, 2014).

\subsection{Statistical analysis and mapping}


is a freeware package that implements most of the basic statistical methods suitable for compositional data (Thio-Henestrosa and Martin-Fernandez, 2006).

$\operatorname{ArcMap}^{\mathrm{TM}}$ was used for spatial analysis of all the data. SPSS 21.0 software was used for statistical analysis, principal component analysis (PCA) on the clr transformed data. All geochemical maps are plotted by inverse distance weighted (IDW). The colour ramp for all geochemical maps used ten division quantile colour ramp. The PCA was performed using the correlation matrix after quartic max rotation and attention was given to the elements with loadings higher than 0.5 or lower than -0.5 .

\section{Results and discussion}

Table 1 and Table 2 provide a summary of the soil and river sediment geochemical data used in this study with a comparison to continental-scale data sets from China. The China soil data set is comprised of topsoil samples $(0-25 \mathrm{~cm})$ and subsoil samples $(>100 \mathrm{~cm})$ collected from 3382 drainage catchments in China by the China soil Geochemical Baselines program (CGB; Wang et al., 2016). The China river sediment data set is comprised of all the samples collected since 1978 in the RGNR program, the median of the data set, after eliminating outliers from a data population with $\mathrm{X} \pm 3 \mathrm{~S}$ as the critical value, is used as an estimate value of geochemical background values (Shi et al., 2016).

Several elements stand out in the Baoshan data set: As, B, Ce, Co, Cr, Cu, F, Ga, Ge, Hg, I, La,

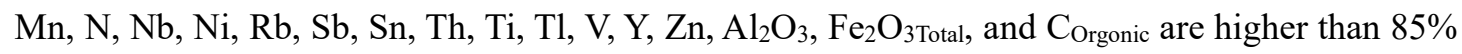
of CGB data which indicates that the element content is significantly higher than the typical value in China, which is called a positive anomaly (Wang et al., 2016). Furthermore, of those elements, the concentrations of $\mathrm{As}, \mathrm{B}, \mathrm{Co}, \mathrm{Cr}, \mathrm{Cu}, \mathrm{Hg}, \mathrm{I}, \mathrm{Mn}, \mathrm{N}, \mathrm{Ni}, \mathrm{Sb}, \mathrm{Sc}, \mathrm{Se}, \mathrm{V}, \mathrm{Fe}_{2} \mathrm{O}_{3 \text { Total }}$ and $\mathrm{C}_{\text {Orgonic }}$ are enriched by approximately a factor of two or more compared to the China data; While $\mathrm{Ba}, \mathrm{Cl}, \mathrm{Sr}$, $\mathrm{SiO}_{2}, \mathrm{CaO}$ and $\mathrm{Na}_{2} \mathrm{O}$ are lower than $25 \%$ of CGB data which indicates that the element content is significantly depleted relative to the typical value, which is called a negative anomaly (Wang et al., 2016). Among those elements, $\mathrm{Sr}, \mathrm{CaO}$ and $\mathrm{Na}_{2} \mathrm{O}$ are depleted by a factor of two to ten compared to the CGB data. By comparison, elements in the river sediment dataset enriched by approximately a factor of two or more in Baoshan area compared to the whole RGNR data set, include As, $\mathrm{B}, \mathrm{CaO}$, 
$\mathrm{Cd}, \mathrm{Co}, \mathrm{Cr}, \mathrm{Cu}, \mathrm{Hg}, \mathrm{Mn}, \mathrm{Ni}, \mathrm{Sb}, \mathrm{V}$ and $\mathrm{Fe}_{2} \mathrm{O}_{3 \text { Total, }}$, whilst $\mathrm{Sr}$ and $\mathrm{Na}_{2} \mathrm{O}$ are depleted.

The following rock groupings were made in order to simplify the spatial distribution of similar rock types across the region: conglomerate, sandstone, siltstone, mudstone, shale and some undivided sediment stratum are combined as Clastic rocks; limestone, dolomite, argillaceous limestone, argillaceous dolomite, calcite dolomite, dolomite limestone, siliceous limestone and chert limestone are combined as Carbonate rocks; basalt, olivine basalt, gabbro and diabase are combined as Basic igneous rocks; muscovite granite, granitoid and dacite are combined as AcidIntermediate rocks; Quaternary stratum are combined as Quaternary; metamorphic rocks (no matter what their origin are) are combined as Metamorphic rocks; finally some unknown rock types are combined as Unknown. Numbers of samples associated with these combined rock groupings and relationship with mineralization are shown in Table S4 (supplementary file).

\subsection{Major element patterns in soil and river sediments}

The geochemical results of major elements for soil and river sediment show distinct spatial patterns in study area as shown by the box plots (Fig. 3) and the plan geochemical maps (Fig. 4).

It is apparent from Fig. 3 that $\mathrm{Mg}$ in surface soil, deep soil and river sediment ( $\mathrm{MgO}$ median: $2.11 \mathrm{wt} . \%$ in surface soil, $1.97 \mathrm{wt} . \%$ in deep soil, $3.65 \mathrm{wt} . \%$ in river sediments) is strongly associated with basic igneous rocks, especially basalt rocks of Carboniferous and Jurassic age distributed in the western and northeast part of the study area (Fig. 4). Similar characteristics can be seen in Fe ( $\mathrm{Fe}_{2} \mathrm{O}_{3 \text { Total }}$ median: $10.60 \mathrm{wt} . \%$ in surface soil, 9.74 wt.\% in deep soil, 9.70 wt.\% in river sediments), and $\mathrm{Ca}(\mathrm{CaO}$ median: $2.11 \mathrm{wt.} \%$ in surface soil, $1.37 \mathrm{wt.} \%$ in deep soil, $5.25 \mathrm{wt.} \%$ in river sediments), their distribution patterns are related to basic igneous rocks and basalt rocks as well. (Fig. 3).

Elements Si and K show similar distribution in soil and river sediment to one another (Fig. 4), the highest concentrations distributed in the central and southeastern parts of study area. The highest median value of $\mathrm{K}$ in surface soil $\left(\mathrm{K}_{2} \mathrm{O}\right.$ median: 3.94 wt. $\left.\%\right)$, deep soil $\left(\mathrm{K}_{2} \mathrm{O}\right.$ median: 3.3 wt. $\left.\%\right)$ and river sediments $\left(\mathrm{K}_{2} \mathrm{O}\right.$ median: $\left.3.60 \mathrm{wt} . \%\right)$ are from samples taken from acid-intermediate rock parent material (Fig. 4). The majority of high $\mathrm{K}$ are, however, related to samples taken from clastic rock parent material $\left(\mathrm{K}_{2} \mathrm{O}\right.$ median: $2.49 \mathrm{wt.} \%$ in surface soil, $2.84 \mathrm{wt} . \%$ in deep soil, and $2.3 \mathrm{wt} . \%$ 
in river sediments, respectively) and metamorphic rock parent material (2.96 wt.\% in surface soil, 2.78 wt.\% in deep soil, and 2.9 wt.\% in river sediments, respectively). The element Si behaves similarly to $\mathrm{K}$, with high median values related to samples from clastic rock and metamorphic rock parent material. The elements $\mathrm{Na}$ and $\mathrm{Al}$ show highest median values in samples taken from acidintermediate rock parent material, and little variation amongst samples sourced from other rock type parent material (Fig. 3).

Organic carbon is relatively higher in samples taken from surface soil taken from Quaternary parent material (Corganic median: $1.74 \mathrm{wt} \%$ in surface soil), relative to samples taken from acidto Corganic, and can be explained by agricultural fertilization in areas with Quaternary parent material. It is also clear from Fig. 4, that there is an observable relationship between Corganic with altitude and intermediate rock parent material ( $\mathrm{C}_{\text {Organic }}$ median: $0.97 \mathrm{wt.} \%$ in surface soil) (Fig. 3). Though not shown by the figures here, it is worth noting that $\mathrm{C}_{\text {Total }}, \mathrm{N}, \mathrm{P}, \mathrm{Br}$, and $\mathrm{S}$ show similar characteristic temperature such that at lower temperatures and higher altitudes carbon turnover is reduced, which results in increased carbon accumulation even under conditions of lower productivity and carbon input.

In summary, high $\mathrm{Fe}, \mathrm{Mg}$, and $\mathrm{Ca}$ concentrations in soil and river sediments are distributed in western and northeastern parts of the study area, and are related to basalts with Carboniferous and Jurassic ages. High Si and $\mathrm{K}$ are distributed in the central and southeastern parts of study area, and are related to acid-intermediate rock parent material, Cambrian- and Ordovician-aged clastic rocks and Precambrian metamorphic rocks. The highest $\mathrm{Na}$ and $\mathrm{Al}$ concentration are related to samples from acid-intermediate rock parent material. Total carbon and $\mathrm{C}_{\text {Organic }}$ in soils are mainly related to altitude and temperature, however, agricultural fertilization in Quaternary areas has caused its enrichment in surface soils (Fig. 4).

\subsection{Spatial patterns of trace elements in soil and river sediments}

The box plots presented for trace elements typically associated with basic igneous rocks $(\mathrm{Cr}$, $\mathrm{Co}, \mathrm{Ni}, \mathrm{Mn}, \mathrm{Cu}, \mathrm{V}$ and $\mathrm{Sc}$ (not showed); Fig. 5), acid-intermediate rocks (La, Sr, Li, Ce (not showed) and $\mathrm{Rb}$ (not showed); Fig. 5) or mineralization-style typical in the study area ( $\mathrm{Pb}, \mathrm{Zn}, \mathrm{Cd}, \mathrm{As}, \mathrm{Sb}$ 
and Hg; Fig. 6).

Chromium, Co and $\mathrm{Ni}$ are enriched in basic igneous rocks, and therefore exhibit obviously high values in overlying soil and nearby river sediments. The highest median values for $\operatorname{Cr}(183.96$ $\mu \mathrm{g} / \mathrm{g}$ in surface soil, $161.14 \mu \mathrm{g} / \mathrm{g}$ in deep soil, and $182.75 \mu \mathrm{g} / \mathrm{g}$ in river sediments), $\mathrm{Ni}(77.88 \mu \mathrm{g} / \mathrm{g}$ in surface soil, $72.17 \mu \mathrm{g} / \mathrm{g}$ in deep soil, and $75.85 \mu \mathrm{g} / \mathrm{g}$ in river sediments) and Co $(38.26 \mu \mathrm{g} / \mathrm{g}$ in surface soil, $34.04 \mu \mathrm{g} / \mathrm{g}$ in deep soil, and $37.55 \mu \mathrm{g} / \mathrm{g}$ in river sediments) occur in those samples comprised of mostly basic igneous rock parent material (Fig. 5). Similar distribution characteristics are also observed with $\mathrm{Fe}$ and $\mathrm{Mg}$. The highest concentrations of $\mathrm{Cr}, \mathrm{Co}$ and $\mathrm{Ni}$ mainly occurred in the western and northeastern parts of the study area (Fig. 7), where Carboniferous and Jurassic basalt rocks are present. Cobalt, $\mathrm{Ni}, \mathrm{Mn}, \mathrm{Cu}, \mathrm{V}$ and $\mathrm{Sc}$ (not showed) show similar patterns to $\mathrm{Cr}$.

Lanthanum, $\mathrm{Sr}, \mathrm{Li}, \mathrm{Ce}$, and $\mathrm{Rb}$ are typically higher in samples taken from acid-intermediate rock parent material than in samples from basic rock parent material. The content of La is conspicuously higher in soil and river sediments related to acid-intermediate rocks (median value: $72.87 \mu \mathrm{g} / \mathrm{g}$ in surface soil, $89.15 \mu \mathrm{g} / \mathrm{g}$ in deep soil, and $65.5 \mu \mathrm{g} / \mathrm{g}$ in river sediments, respectively), and similar with $\mathrm{Sr}$ (median value: $108.30 \mu \mathrm{g} / \mathrm{g}$ in surface soil, $93.43 \mu \mathrm{g} / \mathrm{g}$ in deep soil, and $123.50 \mu \mathrm{g} / \mathrm{g}$ in river sediments, respectively) (Fig. 5). High concentrations of La are distributed in all parts of the study area with basic igneous rocks, carbonate rocks and Precambrian metamorphic rocks (Fig. 7). Cerium, $\mathrm{Rb}$ and $\mathrm{Li}$ are not shown but have similar patterns to La. Furthermore, similar to K, high $\mathrm{Rb}$ (not shown) concentrations show a similar distribution to Cambrian- and Ordovician-aged clastic rocks and Precambrian metamorphic rocks in the study area. This may relate to the substitution of $\mathrm{Rb}$ for $\mathrm{K}$ in potassium-feldspars. Similar to the distribution of $\mathrm{Ca}$, high $\mathrm{Sr}$ (not showed) concentrations are related to carbonate rocks and basic igneous rocks. This is probably related to $\mathrm{Sr}$ being known to substitute for $\mathrm{Ca}$ in minerals such as feldspars and carbonates.

Lead concentration is elevated in those samples taken adjacent to zinc-lead and copper mineralization (Fig. 6), that is mainly distributed in the middle north and middle south of the study area (Fig. 7). Zinc and $\mathrm{Cd}$ are not shown but show similar distributions to $\mathrm{Pb}$. The highest $\mathrm{Hg}$, As (not showed) and $\mathrm{Sb}$ (not showed) concentrations occur in samples adjacent to mercury mineralization. Samples with high concentrations of $\mathrm{Hg}$, As and $\mathrm{Sb}$ also occur adjacent copper-leadzinc deposits (Fig. 7). In the box plots (Fig. 6) the concentrations of $\mathrm{Hg}$, As and $\mathrm{Sb}$ are similar between samples taken adjacent the mercury deposit and samples taken adjacent to other types of 


\subsection{Natural impacts on elements distribution in soil} and river sediments

Except for Corganic and related organic matter related elements in surface soil in Quaternary area talked above, the distribution patterns of element described above reflects the interaction of geological background (parent materials and mineralization) and geomorphology. To find the geochemical associations and spatial distribution between the elements in soil and river sediments, and to simplify the variables to find the main controlling factors of the distribution of elements in

\subsection{Surface soil}

Five PCs accounting for $63.9 \%$ of the total variance were identified using a scree plot. The results of each PC and the PC geochemical maps are shown in Fig. 8, where the geological, mineralization, altitude contour and land-use maps are also presented to help the comparison. The low proportion of the variance for each PC reflects the complexity of soil composition in the Baoshan area. The following observations were made:

PC1: clr. Co (-0.82), clr. Cr (-0.89), clr. Cu (-0.83), clr. Ni (-0.81), clr. Sc (-0.85), clr. Ti (-0.70), clr. $\mathrm{V}(-0.88)$, clr. $\mathrm{Fe}_{2} \mathrm{O}_{3 \text { Total }}(-0.86)$, clr. $\mathrm{MgO}(-0.61)$ are associated with high negative loadings. The distribution of these siderophile elements in soil clearly shows the influence of basic igneous rock (especially basaltic rock) parent material, and the presence of typical mafic minerals including pyroxene (Mg, Fe, $\mathrm{Ca}, \mathrm{V}, \mathrm{Ti}, \mathrm{Cr}, \mathrm{Sc})$, olivine (Fe, Mg, Ni), amphibole (Fe, $\mathrm{Mg}$ ), chromite (Fe, $\mathrm{Mg}$, Cr), titanite (Ti, Fe), and serpentine (Co, Cr, Ni; Cabral Pinto et al., 2017). Conversely, lithophile elements are associated with high positive loadings: clr. B (0.71), clr. Ba (0.51), clr. Be (0.51), clr. Bi (0.57), clr. Ce (0.71), clr. F (0.55), clr. La (0.69), clr. Rb (0.88), clr. Sn (0.63), clr. Th (0.79), clr. $\mathrm{Tl}(0.73)$, clr. $\mathrm{U}(0.54)$, clr. $\mathrm{K}_{2} \mathrm{O}(0.77)$. The distributions of these elements are associates with soils sourced from clastic rock parent material in the middle of study area, and acid-intermediate rock parent material in the east of the study area. 
PC2: clr. $\mathrm{Br}(-0.53)$, clr. N (-0.90), clr. P (-0.70), clr.S (-0.82), clr. $\mathrm{C}_{\text {Organic }}(-0.91)$, clr. $\mathrm{C}_{\text {Total }}(-$ 0.88) have high negative loadings, related to soils located in the higher altitude middle and northeastern parts of the study area. Lower temperature in these higher altitude areas limits organic matter turnover, which results in their increased accumulation even under conditions of lower productivity of organic related elements input. This is comparable to findings in other studies in southeast Germany (Bavaria) and Switzerland looking at organic carbon storage (Leifeld et al., 2005; Wiesmeier et al., 2013). While, this PC is also in a minor related to the agricultural fertilization in Quaternary areas show little reflect the as previous chapter talked. According to the World Bank (2010), China is now the world's largest consumer of chemical fertilizers. The farmland (paddy land) in study area mainly distributed in the flat terrain with lower altitude (Fig 1 and Fig 2a). The lower altitude and flat topography provided convenient for agricultural fertilization. The fertilizers used in China and study area are mainly inorganic fertilizers $\left(\mathrm{N}, \mathrm{P}_{2} \mathrm{O}_{5}, \mathrm{~K}_{2} \mathrm{O}\right)$ and minor organic fertilizer (Fan et al., 2005; Li et al., 2012). The agricultural fertilization may play an important role to those nutrient elements in surface soil of paddy land in the Quaternary areas in the middle area of study area.

PC3: clr. As (-0.67), clr. Hg (-0.76), clr. Sb (-0.74) are strongly associated with high negative loadings from samples adjacent mercury and copper-lead-zinc deposits. The clr. Ga (0.80) and clr. $\mathrm{Al}_{2} \mathrm{O}_{3}(0.78)$ with high positive loadings are associated with samples taken from clastic rock parent material.

PC4: $\mathrm{pH}(-0.80)$, clr. $\mathrm{Sr}(-0.53)$, clr. $\mathrm{MgO}(-0.55)$, clr. $\mathrm{CaO}(-0.82)$ are associated with negative loadings and clr. $\mathrm{Br}(0.50)$, clr.I (0.54), clr. Mo (0.54), clr. Se (0.75) are associated with positive loadings. This PC reflects the influence of parent materials such as: samples sourced from basalt rock, Quaternary or carbonate rock parent material show higher $\mathrm{pH}$ values and $\mathrm{CaO}, \mathrm{Sr}$ and $\mathrm{MgO}$ concentrations, and lower $\mathrm{Br}$, I, Mo and Se concentrations compares to samples taken from soil derived from other rock type parent material. However, when compared to the land-use map, this PC shows similarity to the spatial distribution of land-use: specifically, the soil data overlying paddy land $(\mathrm{pH}=7.37)$, grassland $(\mathrm{pH}=7.15)$, dry cultivated land $(\mathrm{pH}=6.59)$, garden plot $(\mathrm{pH}=6.42)$ and forest land $(\mathrm{pH}=6.04)$. The higher $\mathrm{pH}$ value in paddy land and grass land and lower $\mathrm{pH}$ value in forest land, garden plot, and dry cultivated land was also found by other researchers (Han et al., 2007; Islam and Weil, 2000; Barré et al., 2017; Marzaioli et al., 2010; Qin et al., 2016). 
PC5: clr. Ag (-0.58), clr. Cd (-0.67), clr. Pb (-0.61), clr. Zn (-0.74) shows strongly negative loadings. This PC is associated with soil samples near the copper-lead-zinc deposits in the study area. The association of this group of elements is due to $\mathrm{Pb}$ coexisting with $\mathrm{Zn}$ in the internal growth of a crystal lattice (Mitchell, 1960), and Cd substituting for Zn due to their analogous nature (Alvarezayuso and Garciasanchez, 2003). The association of those elements is also be found in Geochemical Mapping of Agricultural and Grazing Land Soil project (GEMAS) data set (Birke et al 2017).

\section{1.2 Deep soil}

Four PCs accounting for $55.4 \%$ of the total variance were identified using a scree plot. The results of each PC and the PC geochemical maps are shown in Fig. 9. The following observations were made:

PC1: clr. Co (-0.83), clr. Cr (-0.90), clr. Cu (-0.78), clr. Ni (-0.79), clr. Sc (-0.88), clr. Ti (-0.82), clr. V (-0.93), clr. $\mathrm{Fe}_{2} \mathrm{O}_{3 \mathrm{Total}}(-0.90)$ show high negative loadings. Similar to the surface soil PC1, these elements are associated with samples from soil derived from basic rock parent material. The clr. B (0.53), clr. $\mathrm{Rb}(0.69)$, clr. $\mathrm{Sn}(0.52)$, clr. Th (0.66), clr. Tl (0.61), clr. $\mathrm{K}_{2} \mathrm{O}(0.63)$ have positive loadings. The distribution of these elements is associated with soil sourced from clastic rock parent material in the middle of study area, and acid-intermediate rock parent material in the east.

PC2: clr. $\mathrm{SiO}_{2}(0.61)$, clr. $\mathrm{Al}_{2} \mathrm{O}_{3}(0.85)$, clr. $\mathrm{K}_{2} \mathrm{O}$ (0.56), clr. $\mathrm{Ba}(0.58)$, clr. $\mathrm{Be}(0.54)$, clr. Ce (0.57), clr. Ga (0.82), clr.Ge (0.60), clr. $\mathrm{Nb}(0.57)$, clr. Rb (0.61), clr. Sn (0.61), clr. Th (0.56) are associated with positive loadings. Those Samples were taken from soil sourced from clastic rock parent material. The clr. Ag (-0.54), clr. As (-0.50), clr. Cd (-0.70), clr. Hg (-0.55), clr. Sb (-0.53), clr. Zn (-0.56) are strongly associated with negative loadings, and are associated with soil mainly near the $\mathrm{Hg}$ deposit and copper-lead-zinc deposits.

PC3: clr. Br (-0.63), clr. N (-0.77), clr. S (-0.80), clr. C Crgonic (-0.83), clr. $\mathrm{C}_{\text {Total }}(-0.76)$ shows high negative loadings, related to soil from the relative higher altitude areas in the middle and northeast of the study area as surface soil described.

PC4: $\mathrm{pH}(-0.83)$ and clr.CaO (-0.83) are associated with high negative loadings and clr. Se (0.73) shows positive loading. Similar to the surface soil PC4, these elements mainly controlled by 
parent material: samples sourced from basalt rock, Quaternary or carbonate rock parent material show higher $\mathrm{pH}$ values and $\mathrm{CaO}$ concentrations compares to samples taken from soil derived from other rock type parent material; and by a small but important contribution from land-use: the soils from forest land, garden plot and dry cultivated land show lower $\mathrm{pH}$ values than grassland and paddy land.

\section{1. 3 River sediments}

Three PCs accounting for $52.3 \%$ of the total variance were identified using a scree plot. The results of each PC and the PC geochemical maps are shown in Fig. 10. The following observations were made:

PC1: clr. $\mathrm{MgO}(-0.55)$, clr. Co (-0.88), clr. Cr (-0.93), clr. Cu (-0.79), clr. Ni (-0.86), clr. Ti (0.62), clr. V (-0.89), clr. $\mathrm{Fe}_{2} \mathrm{O}_{3 \text { Total }}(-0.77)$ shows high negative loadings. The distribution of this group of siderophile elements is associated with river sediments near basic igneous rocks. Conversely, the lithophile elements clr. B (0.61), clr. Ba (0.53), clr. Be (0.58), clr. F (0.58), clr. Th (0.56), clr. $\mathrm{U}(0.55)$, clr. $\mathrm{W}(0.51)$, clr. $\mathrm{Zr}(0.54)$, clr. $\mathrm{K}_{2} \mathrm{O}$ (0.73) show positive loadings. The distribution of these elements is associated with river sediments with a clastic rocks source in the middle of the study area, and acid-intermediate rocks in the east of the study area. The distribution of this PC, similar to soil, shows that those elements are proximal to the source they were weathered from.

PC2: clr. Sb (-0.81), clr. As (-0.77), clr. Hg (-0.62), shows high negative loadings associated with river sediments near the mercury and copper-lead-zinc deposits. The clr. $\mathrm{Al}_{2} \mathrm{O}_{3}(0.56)$ and clr. $\mathrm{Nb}(0.52)$ show high positive loadings, and are associated with clastic rocks and acid-intermediate rocks.

PC3: clr. $\mathrm{Ag}(-0.58)$, clr. $\mathrm{Cd}(-0.72)$, clr. Pb (-0.73), clr. Zn (-0.81) show strong negative loadings associated with samples near the copper-lead-zin deposits in study area.

In summary, the spatial distribution of these PCs in soil and river sediments reflects the geological and geographical factors of the study area, clearly showing the PC1 in surface soil, deep soil and river sediments are associated with parent materials; PC3 and PC5 in surface soil, PC2 in deep soil, and PC2 and PC3 in river sediment are associated with mineralization; PC2 in surface 
soil and PC3 in deep soil are mainly associated with altitude, however, agricultural fertilization is also shown to contribute in a minor way to PC2 in surface soil; PC4 in surface soil and deep soil are associated with parent materials, however, land-use is also shown to contribute in a minor way to PC4.

\subsection{Anthropogenic impacts}

Due to human activities (agricultural fertilizer, urbanization, industries, and mining activities), the fertility of soil can be decreased; especially where the natural background of PTMs is already high due to the nature of the parental material. To assess the anthropogenic impacts, soil contamination assessment was done by calculation of the enrichment factor (EF), which is a widely used proxy (e.g. Akopyan et al., 2018; Barbieri, 2016; Bern et al., 2019; Cevik et al., 2009; Ghrefat et al., 2011; Liénard et al., 2014; Thiombane et al., 2019; Zhang et al., 2014). The deep soil of the NGSLQ program in China shows little effect of human activities. The chemical composition of deep soil is similar to the parent materials, and is used as the soil geochemical background (Cheng et al., 2014b). Aluminum, Ti and $\mathrm{Zr}$ are known as immobile element during weathering, they could be used as reference elements to calculate the enrichment factor (Balls et al., 1997; Chen et al., 2007; Horowitz et al., 1988; Reimann and Caritat, 2005; Schropp and others, 1990; Trefry and others 1985). In this paper, Ti is used as a reference and the following formula was used (Eq. 1):

$$
\text { (1) } \quad \mathrm{EF}=\left(\mathrm{C}_{\mathrm{X}} / \mathrm{C}_{\mathrm{Ti}}\right)_{\text {surface }} /\left(\mathrm{C}_{\mathrm{X}} / \mathrm{C}_{\mathrm{Ti}}\right)_{\text {deep }}
$$

Where $\mathrm{C}_{\mathrm{x}}$ and $\mathrm{C}_{\mathrm{Ti}}$ represent the concentration of element $\mathrm{x}$ and Ti, respectively.

The numerical results are indicative of different contaminate level. Values of $\mathrm{EF} \approx 1$ suggest that the trace metal concentration may come entirely from natural weathering processes. However, an $\mathrm{EF}>1$ indicates that a significant portion of the trace metals was delivered from anthropogenic materials (Guo et al., 2014). Barbieri (2016) gave the following interpretation for the enrichment factor: $\mathrm{EF}<2$, deficient to minimal enrichment; $2<\mathrm{EF}<5$, moderate enrichment; $5<\mathrm{EF}<20$, significant enrichment; $20<\mathrm{EF}<40$, very high enrichment; $\mathrm{EF}>40$, extremely high enrichment.

For most samples in this study $\mathrm{EF} \approx 1$, which means the concentration of elements are equal in surface soil and deep soil (background). In some samples, however, EF $>1$ are shown in Fig. S3 (supplementary file). The locations of samples with enrichment of $\mathrm{Hg}, \mathrm{As}, \mathrm{Sb}, \mathrm{Cu}, \mathrm{Pb}, \mathrm{Zn}, \mathrm{Cd}$ with 
the EF $>2$ in surface soil are shown in Fig. S4 (supplementary file), they are mainly located near mine areas. This indicates the contributions of mine activities to the surface soil PTMs (incl. Hg, $\mathrm{As}, \mathrm{Sb}, \mathrm{Cu}, \mathrm{Pb}, \mathrm{Zn}$, and $\mathrm{Cd}$ ). As showed in Fig. S4 (supplementary file), mercury, copper-lead-zinc, titanium-iron, nickel, coal and gold mineralization and deposits are widely distributed in the study area and they have been massively mined during latest $20-30$ years. For $\mathrm{Pb}, \mathrm{Zn}$ and $\mathrm{Cu}$, the enrichment in surface soil mainly occurs within $2 \mathrm{~km}$ of copper-lead-zinc deposits. For $\mathrm{Cd}$, the enrichment in surface soil is widely distributed in the study area, and it is highly coincidence with the distribution of PC5 in surface soil. For $\mathrm{Hg}$, As and Sb the enrichment in surface soil is mainly

\section{Conclusion}


surface soil, deep soil and river sediments, and the factors that influence their distribution in Baoshan area, Yunnan province, China.

The statistical summary for soil and river sediments in Baoshan area shows that the elements As, B, (Br), Co, Cr, Cu, Hg, (I), Mn, (N), Ni, Sb, (Sc), (Se), V, $\mathrm{Fe}_{2} \mathrm{O}_{3 \text { Total }}$ and (Corgonic) concentrations are enriched in the Baoshan area compared to the CGB and RGNR data set. The elements Sr and $\mathrm{Na}_{2} \mathrm{O}$ are depleted compared to the CGB and RGNR data set.

By combining single element geochemical, geological, mineralization, altitude, temperature and land-use maps, the median value of differing rock types and the relationship to mineralization, the factors influencing elements in soil and river sediments in the study area were investigated. The distribution of most elements are controlled by the geological parent material: $\mathrm{Co}, \mathrm{Cr}, \mathrm{Cu}, \mathrm{Ni}, \mathrm{Sc}$, Ti, $\mathrm{V}, \mathrm{Fe}_{2} \mathrm{O}_{3 \text { Total }}, \mathrm{MgO}$ are controlled by basic rock sources; $\mathrm{As}, \mathrm{Hg}, \mathrm{Sb},(\mathrm{Ag}), \mathrm{Cd}, \mathrm{Pb}, \mathrm{Zn}$ are controlled by mineralization; other elements are largely controlled by clastic rocks and acidintermediate rocks; $\mathrm{Ca}, \mathrm{Mg}, \mathrm{Sr}$ and $\mathrm{pH}$ are mainly controlled by basalt rock, carbonate rock and Quaternary sources. However, land-use also has a minor contribution to the distribution of $\mathrm{Ca}, \mathrm{Mg}$, $\mathrm{Sr}$ and $\mathrm{pH}$. While $\mathrm{C}_{\text {Total }}, \mathrm{Br}, \mathrm{N},(\mathrm{P}), \mathrm{S}$, and $\mathrm{C}_{\text {Orgonic }}$ in soil was controlled by geomorphic (altitude/temperature) changes, but agricultural fertilization in Quaternary area has caused those elements enrichment in surface soil.

Finally, anthropogenic factors (mining activities) have also been recognized in the soil data set and are responsible for the surface soil contamination by PTMs (incl. $\mathrm{Hg}, \mathrm{As}, \mathrm{Sb}, \mathrm{Cu}, \mathrm{Pb}, \mathrm{Zn}, \mathrm{Cd}$ ) near mining areas.

\section{Acknowledgements}

The authors would like to thank the funding provided by China Geological Survey (DD20160313) and Ministry of Finance of PRC Foundation (121201108000168530) and China Scholarship Council (CSC201868110267). Acknowledgement for the data support from "National Earth System Science Data Sharing Infrastructure, National Science \& Technology Infrastructure of China. (http://www.geodata.cn)". We would like to appreciate to all of the participants from Division of Geochemical Survey Methodology, IGGE for the field work. Thanks to Dr. Jian Zhou from International Centre on Global-Scale Geochemistry, UNESCO and Dr. Bingli Liu from 


\section{Reference}

Addo, M. A., Darko, E. 0., Gordon, C., Nyarko, B. J. B., Gbadago, J. K., Nyarko, E., Affum, H. A., Botwe, B. 0., 2012. Evaluation of Heavy Metals Contamination of Soil and Vegetation in the Vicinity of a Cement Factory in the Volta Region, Ghana. International Journal of Science \& Technology 2, 40-50.

Aitchison, J., 1981. A new approach to null correlations of proportions. Journal of the International Association for Mathematical Geology 13, 175-189.

Aitchison, J., 1982. The statistical analysis of compositional data (with discussion). J. R. Stat. Soc. Ser. B Stat Methodol. 44 (2), $139-177$.

Aitchison, J., 1986. The statistical analysis of compositional data. Monographs on statistics and applied probability. London (UK). Chapman \& Hall Ltd., London (UK) (Reprinted in 2003 with additional material by The Blackburn Press). 416 p.

Albanese, S., De Vivo, B., Lima, A., Cicchella, D., 2007. Geochemical background and baseline values of toxic elements in stream sediments of Campania region (Italy). Journal of Geochemical Exploration. 93, $21-34$.

Akopyan, K., Petrosyan, V., Grigoryan, R., Melkom Melkomian, D., 2018. Assessment of residential soil contamination with arsenic and lead in mining and smelting towns of northern Armenia. Journal of Geochemical Exploration 184, 97-109.

Alvarezayuso, E., Garciasanchez, A., 2003. Sepiolite as a feasible soil additive for the immobilization of cadmium and zinc. Science of The Total Environment 305, 1-12.

Antibachi, D., Kelepertzis, E., Kelepertsis, A., 2012. Heavy Metals in Agricultural Soils of the Mouriki-Thiva Area (Central Greece) and Environmental Impact Implications. Soil and Sediment Contamination: An International Journal 21, 434-450.

Barré, P., Durand, H., Chenu, C., Meunier, P., Montagne, D., Castel, G., Billiou, D., Soucémarianadin, L., Cécillon, L., 2017. Geological control of soil organic carbon and nitrogen stocks at the landscape scale. Geoderma 285, 50-56.

Balls, P.W., Hull, S., Miller, B. S., Pirie, J.M., Proctor W., 1997. Trace metal in Scottish estuarine and coastal sediments. Mar Pollut Bull 34: 42-50.

Barbieri, M., 2016. The Importance of Enrichment Factor (EF) and Geoaccumulation Index (Igeo) to Evaluate the Soil Contamination. Journal of Geology \& Geophysics. 5.

Barsby, A., McKinley, J. M., Ofterdinger, U., Young, M., Cave, M. R., Wragg, J., 2012. Bioaccessibility of trace elements in soils in Northern Ireland. Sci Total Environ 433, $398-417$.

Becquer, T., Quantin, C., Rotte-Capet, S., Ghanbaja, J., Mustin, C., Herbillon, A. J., 2006. Sources of trace metals in Ferralsols in New Caledonia. European Journal of Soil Science 57, 200-213. 
Bern, C. R., Walton-Day, K., Naftz, D. L., 2019. Improved enrichment factor calculations through principal component analysis: Examples from soils near breccia pipe uranium mines, Arizona, USA. Environ Pollut 248, 90-100.

Birke, M., Reimann, C., Rauch, U., Ladenberger, A., Demetriades, A., Jähne-Klingberg, F., Oorts, K., Gosar, M., Dinelli, E., Halamić, J., 2017. GEMAS: Cadmium distribution and its sources in agricultural and grazing land soil of Europe - Original data versus clrtransformed data. Journal of Geochemical Exploration 173, 13-30.

Bompoti, N., Chrysochoou, M., Dermatas, D., 2015. Geochemical Characterization of Greek Ophiolitic Environments Using Statistical Analysis. Environmental Processes 2, 5-21.

Bonifacio, E., Falsone, G., Piazza, S., 2010. Linking Ni and $\mathrm{Cr}$ concentrations to soil mineralogy: does it help to assess metal contamination when the natural background is high? Journal of Soils and Sediments 10, 1475-1486.

Boogaart, K., Tolosana-Delgado, R., 2013. Analyzing Compositional Data with R. 73-93.

Callender, E., Rice, K.C., 2000. The urban environmental gradient: anthropogenic influences on the spatial and temporal distributions of lead and zinc in sediments. Environ. Sci. Technol. 34, $232-238$.

Cabral Pinto, M. M. S., Silva, M. M. V.G., Ferreira da Silva, E.A., Dinis, P.A., Rocha, F., 2017. Transfer processes of potentially toxic elements (PTE) from rocks to soils and the origin of PTE in soils: A case study on the island of Santiago (Cape Verde). Journal of Geochemical Exploration 183, 140-151.

Cevik, F., Goksu, M. Z., Derici, 0. B., Findik, 0., 2009. An assessment of metal pollution in surface sediments of Seyhan dam by using enrichment factor, geoaccumulation index and statistical analyses. Environ Monit Assess 152, 309-317.

CGS, 2005. Specification for multi-purpose regional geochemical survey (DD2005-01), in: China Geological Survey (Ed.), Beijing. (In Chinese)

CGS, 2014. Specification for multi-purpose regional geochemical survey (DD/T 0258-2014), in: China Geological Survey (Ed.), Beijing. (In Chinese)

Chayes, F., 1960. On correlation between variables of constant sum. J. Geophys. Res. 65 (12), $4185-4193$.

Chen, CW., Kao, CM., Chen, CF., Dong, C. D., 2007. Distribution and accumulation of heavy metals in the sediments of Kaohsiung Harbor, Taiwan. Chemosphere, 66 (8), $1431-1440$.

Chen, J., Tan, M., Li, Y., Zhang, Y., Lu, W., Tong, Y., Lu, W., Tong, Y., Zhang, G., Li, Y., 2005. A lead isotope record of shanghai atmospheric lead emissions in total suspended particles during the period of phasing out of leaded gasoline. Atmospheric Environment, $39(7), \quad 1245-1253$.

Cheng, H.X., Li, M. , Xie, X. J., Yang, Z.F., Li, C., 2014a. Exploring China: Environment and Resources. Journal of Geochemical Exploration: Journal of the Association of Exploration Geochemists, $1-216$.

Cheng H.X., Li K., Li M., Yang K., Liu F., Cheng X. M., 2014b. Geochemical background and baseline value of chemical elements in urban soil in China. Earth Science Frontiers, 21(3): 265-306. (in Chinese with English abstract)

Cheng X.M., 2016. Geochemical Behavior and Risk Analysis for heavy Elements in Soil Profiles with Different Parent Material, Yunnan Province, China. (in Chinese with English abstract) 
Chiu, Y.P., Li, D.W., Shiau, Y.C., 2016. Study on Heavy Metal Characteristics of Soil in Phosphorus Tail. Journal of residuals science and technology. 13.

Cicchella, D., De, V.B., Lima, A., Albanese, S., Mc, G. R. A. R., Parrish, R. R., 2008. Heavy metal pollution and $\mathrm{Pb}$ isotopes in urban soils of Napoli, Italy. Geochemistry Exploration Environment Analysis 8, 103-112.

Cicchella, D., Hoogewerff, J., Albanese, S., Adamo, P., Lima, A., Taiani, M. V. E., Benedetto De Vivo, B., 2016. Distribution of toxic elements and transfer from the environment to humans traced by using lead isotopes. a case of study in the sarno river basin, south italy. Environmental Geochemistry and Health, 38(2), 619-637.

Cox, S.F., Rollinson, G., McKinley, J.M., 2017. Mineralogical characterisation to improve understanding of oral bioaccessibility of $\mathrm{Cr}$ and $\mathrm{Ni}$ in basaltic soils in Northern Ireland. Journal of Geochemical Exploration 183, 166-177.

Darnley, A., Garrett, R.G., 1990. International Geochemical Mapping Special Issue. Journal of Geochemical Exploration. 39.

Darnley, A. G., Bjiirklund, A., Belviken, B., Gustavsson, N., Koval, P. V., Plant, J. A. , Steenfelt, A., Tauchid, M., Xuejing, X., 1995. A Global Geochemical Database for Environmental and Resource Management: Recommendations for International Geochemical Mapping: Final Report of IGCP Project 259. UNESCO Publishing.

Dokuchaev V.V., 1967. Russian Chernozem, in selected works of V. V. Dokuchaev, Moscow, 1948, 1, 14 - 419. Israel Program for Scientific Translations Ltd. (for USDA- NSF), Publ. by S. Monson, Jerusalem (Transl. into English by N. Kaner)

Dong, M., Dong, G., Mo, X., Santosh, M., Zhu, D., Yu, J., Nie, F., Hu, Z., 2013. Geochemistry, zircon $\mathrm{U}-\mathrm{Pb}$ geochronology and $\mathrm{Hf}$ isotopes of granites in the Baoshan Block, Western Yunnan: Implications for Early Paleozoic evolution along the Gondwana margin. Lithos 179, $36-47$.

Egozcue, J. J., Pawlowsky-Glahn, V., Mateu-Figueras, G., Barceló-Vidal, C., 2003. Isometric Logratio Transformations for Compositional Data Analysis. Mathematical Geology 35, 279300 .

Fan, M., Zheng, Y., Li, S., Mao, K., Yin, S., \& Zhou, H., 2005. Nutrient cycling and balance of agro-ecosystem in Baoshan, Yunnan Province. Journal of Yunnan Agricultural University, 20 (3), 415-418. (in Chinese with English abstract)

Gałuszka, A., 2007. Different approaches in using and understanding the term "Geochemical background" - Practical implications for environmental studies. Polish J. Environ. Stud. $16, \quad 389-395$.

Ghrefat, H.A., Abu-Rukah, Y., Rosen, M.A., 2011. Application of geoaccumulation index and enrichment factor for assessing metal contamination in the sediments of Kafrain Dam, Jordan. Environ Monit Assess 178, 95-109.

Goldhaber, M. B., Morrison, J.M., Holloway, J. M. , Wanty, R. B., Helse1, D. R., Smith, D. B., 2009. A regional soil and sediment geochemical study in northern California. Applied Geochemistry 24, $1482-1499$.

Guo, X.X., Liu, C.Q., Zhu, Z.Z., Wang, Z. L., Li, J., 2011. Evaluation methods for soil heavy metals contamination: A review. Chinese Journal of Ecology, 30(5):889-896. (in Chinese with English abstract)

Jenny, H., 1941. Factors of Soil Formation: A System of Quantitative Pedology. New York: 
McGraw-Hill. 281Han S.C., Pu L. J., Chen F., Zhang C.Y., Zhang J., Peng B. Z., 2007, Responses of soil properties to change in land-use in a typical area of the yangtze river delta -a case study of xishan city, jiangsu province, china. Acta Pedologica Sinica. 44(4): 612-319. (in Chinese with English abstract)

Hamzeh, M. A., Aftabi, A., Mirzaee, M., 2011. Assessing geochemical influence of traffic and other vehicle-related activities on heavy metal contamination in urban soils of Kerman city, using a GIS-based approach. Environ Geochem Health 33, 577-594.

Horowitz, A. J, Elrick, K., Callender, E., 1988. The effect of mining on the sediment-trace element geochemistry of cores from the Cheyenne River arm of Lake Oahe, South Dakota, USA. Chem Geol 67: $17-33$.

Islam, K. R., Weil, R.R., 2000. Land use effects on soil quality in a tropical forest ecosystem of Bangladesh. Agriculture, Ecosystems \& Environment 79, 9-16.

Kelepertzis, E., Galanos, E., Mitsis, I., 2013. Origin, mineral speciation and geochemical baseline mapping of $\mathrm{Ni}$ and $\mathrm{Cr}$ in agricultural topsoils of Thiva Valley (central Greece). Journal of Geochemical Exploration 125, 56-68.

Kelepertzis, E., Komárek, M., Argyraki, A., Sillerová, H., 2016. Metal(loid) distribution and $\mathrm{pb}$ isotopic signatures in the urban environment of athens, greece. Environmental Pollution, 213, 420-431.

Leifeld, J., Bassin, S., Fuhrer, J., 2005. Carbon stocks in Swiss agricultural soils predicted by land-use, soil characteristics, and altitude. Agriculture, Ecosystems \& Environment $105,255-266$.

Li, D., Chen, Y., Hou, K., Lu, Z., Cui, D., 2015. Detrital zircon record of Paleozoic and Mesozoic meta-sedimentary strata in the eastern part of the Baoshan block: Implications of their provenance and the tectonic evolution of the southeastern margin of the Tibetan plateau. Lithos 227, 194-204.

Li, M. , Xi, X., Xiao, G., Cheng, H., Yang, Z., Zhou, G., Ye, J., Li, Z., 2014a. National multi-purpose regional geochemical survey in China. Journal of Geochemical Exploration 139, 21-30.

Li, Z., Ma, Z., van der Kuijp, T. J., Yuan, Z., Huang, L., 2014b. A review of soil heavy metal pollution from mines in China: pollution and health risk assessment. Sci Total Environ 468-469, 843-853.

Li, X.H., Cheng, H.X., Zhao, C.D., Xu, X.B., 2010. Mercury contamination in the topsoil and subsoil of urban areas of Beijing, China. Bull Environ Contam Toxicol 85, 224-228.

Li, Y., Fredrich, Kahrl., Pan, J., Roland-Holst, D., Su, Yufang., Wilkes, A., Xu, J., 2012. Fertilizer use patterns in Yunnan Province, China: Implications for agricultural and environmental policy. Agricultural systems, 110, 78-89.

Liénard, A., Brostaux, Y., Colinet, G., 2014. Soil contamination near a former $\mathrm{Zn}-\mathrm{Pb}$ oretreatment plant: Evaluation of deterministic factors and spatial structures at the landscape scale. Journal of Geochemical Exploration 147, 107-116.

Luo, X.S., Yu, S., Zhu, Y.G., Li, X. D., 2012. Trace metal contamination in urban soils of China. Sci Total Environ 421-422, 17-30.

Marzaioli, R., D’ Ascoli, R., De Pascale, R.A., Rutigliano, F.A., 2010. Soil quality in a Mediterranean area of Southern Italy as related to different land use types. Applied Soil Ecology 44, 205-212. 
McGrath, D., Tunney, H., 2010. Accumulation of cadmium, fluorine, magnesium, and zinc in soil after application of phosphate fertilizer for 31 years in a grazing trial. Journal of Plant Nutrition and Soil Science 173, 548-553.

Mckinley, J.M., Hron, K., Grunsky, E.C., Reimann, C., Caritat, P. D., Filzmoser, P., Boogaart, K. G. V. D. , Tolosana-Delgado, R., 2016. The single component geochemical map: Fact or fiction? Journal of Geochemical Exploration 162, 16-28.

Mitchell, R. L., 1960. Trace element problems in Scottish soils. The Proceedings of the Nutrition Society 19, $148-153$.

Pawlowsky-Glahn, V., Buccianti, A., 2011. Compositional data analysis: theory and applications. John Wiley \& Sons (378 p).

Pawlowsky-Glahn, V., Egozcue, J.J., 2001. Geometric approach to statistical analysis on the simplex. Stochastic Environmental Research and Risk Assessment 15, 384-398.

Plant, J., Smith, D., Smith, B., Williams, L., 2001. Environmental geochemistry at the global scale. Applied Geochemistry 16, $1291-1308$.

Poňavič M., Wittlingerová Z., Čoupek P., Jan B., 2018, Soil geochemical mapping of the central part of Prague, Czech Republic. Journal of Geochemical Exploration, 187: 118-130.

Qin C., He B.H., Jiang X. J., 2016. Soil nutrient characteristics of different land-use types in the Tree Gorges Reservoir. Acta Prataculturae Sinica, 25(9): 10-19. (in Chinese with English abstract)

Qu, C., Sun, Y., Albanese, S., Lima, A., Sun, W., Di Bonito, M., Qi, S., De Vivo, B., 2017. Organochlorine pesticides in sediments from Gulfs of Naples and Salerno, Southern Italy. Journal of Geochemical Exploration. 195, 87-96.

Qu, C., Albanese, S., Lima, A., Hope, D., Pond, P., Fortelli, A., Romano, N., Cerino, R., Pizzolante, A., De Vivo, B., 2019. The occurrence of OCPs, PCBs, and PAHs in the soil, air, and bulk deposition of the Naples metropolitan area, southern Italy: Implications for sources and environmental processes. Environment International. 124, 89-97.

Rate, A.W., 2018. Multielement geochemistry identifies the spatial pattern of soil and sediment contamination in an urban parkland, Western Australia. Science of the Total Environment, 627: 1106-1120.

Reimann, C., Arnoldussen, A., Englmaier, P., Filzmoser, P., Finne, T.E., Garrett, R. G., Koller, F., Nordgulen, Ø., 2007. Element concentrations and variations along a $120 \mathrm{~km}$ long transect in south Norway - Anthropogenic vs. Geogenic vs. biogenic element sources and cycles. Appl. Geochem. 22, $851-871$.

Reimann, C., Caritat, P., 2005. Distinguishing between natural and anthropogenic sources for elements in the environment: Regional geochemical surveys versus enrichment factors. Science of The Total Environment. 337, $91-107$.

Reimann, C., Caritat, P., 2017. Establishing geochemical background variation and threshold values for 59 elements in Australian surface soil. Science of The Total Environment. 578, $633-648$.

Sahoo, P. K., Dall'Agnol, R., Salomão, G. N., Junior, J. D. S. F., Silva, M. S., e Souza Filho, P. W. M. , Powe11, M. A., Angélica, R. S., Pontes, P. R. , da Costa, M. F., Siqueira, J. 0., 2019a. High resolution hydrogeochemical survey and estimation of baseline concentrations of trace elements in surface water of the Itacaiúnas River Basin, southeastern Amazonia: Implication for environmental studies. Journal of Geochemical Exploration, 205, 106321. 
Sahoo, P. K., Guimarães, J.T.F., Souza-Filho, P. W. M., Powe11, M. A. , da Silva, M. S., Moraes, A. M. , Alves, R., Leite, A. S., Júnior, W. N., Rodrigues, T. M. , Costa, V. E., Dall'Agnol, E. , 2019b. Statistical analysis of lake sediment geochemical data for understanding surface geological factors and processes: An example from Amazonian upland lakes, Brazil. Catena, $175, \quad 47-62$.

Sahoo, P. K., Dall' Agnol, R., Salomão, G. N., Junior, J. D. S. F., da Silva, M. S., Martins, G. C. , e Souza Filho, P.W.M., Powe11, M.A., Maurity, C.W., Angelica, R. S., da Costa, M. F., Siqueira, J. 0., 2020. Source and background threshold values of potentially toxic elements in soils by multivariate statistics and GIS-based mapping: a high density sampling survey in the Parauapebas basin, Brazilian Amazon. Environmental geochemistry and health, 42(1), $255-282$.

Salomão, G. N., Figueiredo, M. A., Dall'Agnol, R., Sahoo, P. K., de Medeiros Filho, C.A., da Costa, M.F., Angélica, R. S., 2019. Geochemical mapping and background concentrations of iron and potentially toxic elements in active stream sediments from Carajás, Brazil implication for risk assessment. Journal of South American Earth Sciences, 92, 151-166.

Schropp, S. J, Lewis, F. G, Windom, H. L., Ryan, J. D., Calder, F. D., Burney, L. C. , 1990. Interpretation of metal concentrations is estuarine sediments of Florida using aluminum as a reference element. Estuaries 13: $227-235$.

Shi C. Y., Liang M., Feng B., 2015. Average Background Values of 39 Chemical Elements in Stream Sediments of China. Earth Science, 41(2), 234-251. (in Chinese with English abstract)

Tashakor, M., Wan Zuhairi, Y., Mohamad, H., Ghani, A., 2014. Geochemical characteristics of serpentinite soils from Malaysia. Malaysian Journal of Soil Science 18, 35-49.

Teutsch, N., Erel, Y., Halicz, L., Banin, A., 2001. Distribution of natural and anthropogenic lead in mediterranean soils. Geochimica et Cosmochimica Acta, 65(17), 2853-2864

Thio-Henestrosa, S., Martin-Fernandez, J.A., 2006. Detailed guide to CoDaPack: A freeware compositional software. Geological Society London Special Publications 264, 101-118.

Thiombane, M., Di Bonito, M., Albanese, S., Zuzolo, D., Lima, A., De Vivo, B., 2019. Geogenic versus anthropogenic behaviour and geochemical footprint of $\mathrm{Al}$, Na, K and $\mathrm{P}$ in the Campania region (Southern Italy) soils through compositional data analysis and enrichment factor. Geoderma 335, 12-26.

Thomas, V., 1995. The elimination of lead in gasoline. Annual Review Energy Environment, 20 (2), $301-324$.

Tolosana-Delgado, R., McKinley, J., 2016. Exploring the joint compositional variability of major components and trace elements in the Tellus soil geochemistry survey (Northern Ireland). Applied Geochemistry 75, 263-276.

Trefry, J.H, Metz, S., Trocine, R.P., 1985. A decline in lead transport by the Mississippi River. Science 230, $439-441$.

Wang X. Q., Zhou J., Xu S.F., Chi Q.H., Nie L.S., ZhangB. M., YA0 W. S., Wang Wei., Liu., H. L., Liu D.S., Han Z.X., Liu Q. Q., 2016. China soil geochemical baselines networks: Data characteristics. Geology in China, 43(5), 1469-1480. (in Chinese with English abstract)

Wang, X., Liu, X., Han, Z., Zhou, J., Xu, S., Zhang, Q., Chen, H., Bo, W., Xia, X., 2015. Concentration and distribution of mercury in drainage catchment sediment and alluvial soil of China. Journal of Geochemical Exploration 154, 32-48.

Wang, Y., Xing, X., Cawood, P. A., Lai, S., Xia, X., Fan, W., Liu, H., Zhang, F., 2013. 
Petrogenesis of early Paleozoic peraluminous granite in the Sibumasu Block of SW Yunnan and diachronous accretionary orogenesis along the northern margin of Gondwana. Lithos 182, 67-85.

Wang, Y., Zhang, A., Fan, W., Peng, T., Zhang, F., Zhang, Y., Bi, X., 2010. Petrogenesis of late Triassic post-collisional basaltic rocks of the Lancangjiang tectonic zone, southwest China, and tectonic implications for the evolution of the eastern Paleotethys: Geochronological and geochemical constraints. Lithos 120, 529-546.

Wiesmeier, M., Hübner, R., Barthold, F., Spörlein, P., Geuß, U., Hangen, E., Reischl, A., Schilling, B., von Lützow, M., Kögel-Knabner, I., 2013. Amount, distribution and driving factors of soil organic carbon and nitrogen in cropland and grassland soils of southeast Germany (Bavaria). Agriculture, Ecosystems \& Environment 176, 39-52.

(The) World Bank (2010), World Development Indicators 2010, The world Bank, Washington, DC, available at: www. worldbank. org.

Xie, X., Cheng, H., 2014. Sixty years of exploration geochemistry in China. Journal of Geochemical Exploration 139, 4-8.

Xie, X., Wang, X., Zhang, Q., Zhou, G., Cheng, H., Liu, D., Cheng, Z., Xu, S., 2008. Multiscale geochemical mapping in China. Geochemistry: Exploration, Environment, Analysis 8, 333-341.

Yuan, G. L., Sun, T.H., Han, P., Li, J., 2013. Environmental geochemical mapping and multivariate geostatistical analysis of heavy metals in topsoils of a closed steel smelter: Capital Iron \& Steel Factory, Beijing, China. Journal of Geochemical Exploration. 130, $15-21$.

Zhang, H., Luo, Y., Makino, T., Wu, L., Nanzyo, M., 2013. The heavy metal partition in sizefractions of the fine particles in agricultural soils contaminated by waste water and smelter dust. J Hazard Mater 248-249, 303-312.

Zhang, H., Chen, J., Li, Z., Yang, G., Li, D., 2014. Anthropogenic mercury enrichment factors and contributions in soils of Guangdong Province, South China. Journal of Geochemical Exploration 144, 312-319.

Zhang, X.P., Wei, D., Yang, X.M., 2002. The background concentrations of 13 soil trace elements and their relationships to parent materials and vegetation in Xizang (Tibet), China. Journal of Asian Earth Sciences 21, 167-174.

Zheng, K. L., Ye, J.Y., Jiang, B.L., 2005. Selected Analytical Methods of 57 Elements for Multi-purpose Geochemical Survey. Geological Publishing House, Beijing. (in Chinese) 
${ }_{796}$ Tables and Figures

\section{List of Tables and Figures}

798 Table 1 Statistical comparison of Baoshan soil data set with China Soil Geochemical Baselines (CGB) data set.

799 Table 2 Statistical comparison of Baoshan river sediments data set with Regional Geochemistry-National

800 Reconnaissance (RGNR) data set.

801 Fig. 1 Contour maps of altitude, average surface soil $(0 \mathrm{~cm})$ temperature, and annual rainfall for study area.

802 Fig. 2 General situation of study area. (a) Simplified land-use map of study area. (b, c) Simplified tectonic map of

803 Yunnan Sanjiang area. (d) Simplified geological and mineral deposits map of study area (Geological map simplified

804 from Yunnan geological and mineral development bureau regional geological survey team, 1981,1983,1986;

805 Mineralization map from CGS mineral resources database http://geocloud.cgs.gov.cn).

806 Fig. 3 Box plots of major elements of surface soil, deep soil and river sediments according to rock type groupings.

807 Fig. 4 Major elements geochemical maps of surface soil, deep soil and river sediments in study area.

808 Fig. 5 Box plots of trace elements from soil and river sediments according to rock type groupings.

809 Fig. 6 Box plots of trace elements $\mathrm{Pb}, \mathrm{Zn}, \mathrm{Cd}, \mathrm{As}, \mathrm{Hg}, \mathrm{Sb}$ from soil and river sediments according to the relationship

810 with mineralization.

811 Fig. 7 Geochemical maps of trace elements in soil and river sediments. Mineralization occurrences plotted for 812 comparison in $\mathrm{Pb}$ and $\mathrm{Hg}$ geochemical map.

813 Fig. 8 Spatial distribution of PCs of surface soil. Geological, mineralization, altitude and land-use maps are presented 814 for comparison.

815 Fig. 9 Spatial distribution of PCs of deep soil. Geological, mineralization, altitude and land-use maps are presented 816 for comparison.

817 Fig. 10 Spatial distribution of PCs of river sediments. Geological and mineralization maps are presented for 818 comparison. 


\begin{tabular}{|c|c|c|c|c|c|c|c|c|c|}
\hline \multirow{3}{*}{ Elements } & \multirow{3}{*}{ Depths } & \multicolumn{4}{|c|}{ This study } & \multicolumn{4}{|c|}{ CGB data (Wang et al., 2016) } \\
\hline & & \multirow{2}{*}{ Median } & \multirow{2}{*}{ Mean } & \multirow{2}{*}{ Min } & \multirow{2}{*}{$\operatorname{Max}$} & LBGB & BGB & HBGB & AGB \\
\hline & & & & & & $25 \%$ & $50 \%$ & $75 \%$ & $85 \%$ \\
\hline \multirow{2}{*}{$\mathrm{Ag}(\mathrm{ng} / \mathrm{g})$} & Surface & 84 & 103 & 27 & 4203 & 59 & 77 & 102 & 121 \\
\hline & Deep & 78 & 93 & 32 & 2133 & 55 & 70 & 90 & 107 \\
\hline \multirow{2}{*}{$\operatorname{As}(\mu \mathrm{g} / \mathrm{g})$} & Surface & 16.4 & 23.0 & 0.5 & 909.1 & 6 & 9 & 14 & 17 \\
\hline & Deep & 18.7 & 26.7 & 1.8 & 536.8 & 6 & 9 & 13 & 17 \\
\hline \multirow{2}{*}{$\mathrm{Au}(\mathrm{ng} / \mathrm{g})$} & Surface & 1.76 & 2.71 & 0.15 & 285.20 & 0.8 & 1.3 & 2 & 2.6 \\
\hline & Deep & 2.03 & 2.43 & 0.53 & 25.47 & 0.7 & 1.1 & 1.8 & 2.3 \\
\hline \multirow{2}{*}{$\mathrm{B}(\mu \mathrm{g} / \mathrm{g})$} & Surface & 79 & 82 & 8 & 513 & 30 & 43 & 61 & 75 \\
\hline & Deep & 78 & 81 & 20 & 232 & 26 & 41 & 59 & 71 \\
\hline \multirow{2}{*}{$\mathrm{Ba}(\mu \mathrm{g} / \mathrm{g})$} & Surface & 327 & 381 & 105 & 9035 & 427 & 512 & 610 & 665 \\
\hline & Deep & 342 & 390 & 90 & 1556 & 431 & 522 & 628 & 689 \\
\hline \multirow{2}{*}{$\mathrm{Be}(\mu \mathrm{g} / \mathrm{g})$} & Surface & 2.45 & 2.53 & 0.90 & 13.58 & 1.7 & 2 & 2.4 & 2.7 \\
\hline & Deep & 2.70 & 2.80 & 1.33 & 9.42 & 1.6 & 2 & 2.5 & 2.8 \\
\hline \multirow{2}{*}{$\mathrm{Bi}(\mu \mathrm{g} / \mathrm{g})$} & Surface & 0.43 & 0.49 & 0.03 & 7.12 & 0.21 & 0.3 & 0.4 & 0.51 \\
\hline & Deep & 0.45 & 0.49 & 0.17 & 6.47 & 0.19 & 0.27 & 0.37 & 0.46 \\
\hline \multirow{2}{*}{$\mathrm{Br}(\mu \mathrm{g} / \mathrm{g})$} & Surface & 4.58 & 6.12 & 1.19 & 66.84 & 1.5 & 2.2 & 3.5 & 4.5 \\
\hline & Deep & 3.48 & 4.45 & 0.50 & 24.94 & 1.5 & 1.8 & 2.8 & 3.6 \\
\hline \multirow{2}{*}{ Cd (ng/g) } & Surface & 187 & 269 & 15 & 5352 & 96 & 137 & 197 & 261 \\
\hline & Deep & 131 & 200 & 15 & 3215 & 79 & 110 & 159 & 205 \\
\hline \multirow{2}{*}{$\mathrm{Ce}(\mu \mathrm{g} / \mathrm{g})$} & Surface & 90.7 & 90.6 & 27.6 & 237.3 & 50 & 64 & 77 & 86 \\
\hline & Deep & 93.8 & 94.5 & 38.4 & 226.1 & 46 & 62 & 77 & 86 \\
\hline $\mathrm{Cl}(\mathrm{u} / \mathrm{s}$ & Surface & 38 & 45 & 10 & 841 & 55 & 78 & 171 & 538 \\
\hline$C(\mu \mathrm{g} / \mathrm{g})$ & Deep & 39 & 45 & 25 & 370 & 48 & 72 & 164 & 425 \\
\hline Ce & Surface & 22.02 & 24.15 & 2.93 & 72.31 & 8 & 11 & 14 & 16 \\
\hline $\mathrm{Co}(\mu \mathrm{g} / \mathrm{g})$ & Deep & 23.97 & 25.10 & 4.72 & 64.14 & 7 & 11 & 14 & 16 \\
\hline$C r(40)+2$ & Surface & 113 & 128 & 10 & 422 & 37 & 53 & 68 & 79 \\
\hline$(\mu \mathrm{g})$ & Deep & 119 & 130 & 35 & 299 & 33 & 50 & 68 & 79 \\
\hline$C$ & Surface & 40.7 & 48.7 & 3.1 & 652.2 & 14 & 20 & 27 & 33 \\
\hline (u $(\mu \mathrm{g} / \mathrm{g})$ & Deep & 45.2 & 49.5 & 7.1 & 277.4 & 13 & 19 & 26 & 31 \\
\hline For & Surface & 665 & 749 & 146 & 2219 & 372 & 488 & 591 & 657 \\
\hline $\mathrm{F}(\mu \mathrm{g} / \mathrm{g})$ & Deep & 700 & 792 & 289 & 2159 & 343 & 456 & 575 & 648 \\
\hline$C_{0}(0)$ & Surface & 21.2 & 21.2 & 10.1 & 32.9 & 12 & 15 & 18 & 19 \\
\hline$G a(\mu g / g)$ & Deep & 22.6 & 22.7 & 13.9 & 35.4 & 12 & 15 & 18 & 19 \\
\hline Ge & Surface & 1.64 & 1.67 & 0.70 & 4.39 & 1.1 & 1.3 & 1.5 & 1.6 \\
\hline$\sigma^{\prime}(\mu g / g)$ & Deep & 1.75 & 1.78 & 0.35 & 5.16 & 1.1 & 1.3 & 1.5 & 1.6 \\
\hline & Surface & 105 & 178 & 4 & 6813 & 13 & 26 & 56 & 87 \\
\hline Hg (ng/g) & Deep & 112 & 135 & 19 & 2353 & 11 & 18 & 36 & 55 \\
\hline $\mathrm{H}$ & Surface & 4.95 & 5.52 & 0.39 & 29.01 & 0.7 & 1.1 & 1.8 & 2.3 \\
\hline $1(\mu \mathrm{g} g)$ & Deep & 4.76 & 5.13 & 0.66 & 17.91 & 0.6 & 1 & 1.7 & 2.4 \\
\hline $\mathrm{J}$ & Surface & 47.5 & 47.7 & 13.6 & 112.5 & 25 & 33 & 40 & 44 \\
\hline$L d(\mu g / g)$ & Deep & 47.5 & 48.9 & 21.4 & 139.3 & 23 & 32 & 39 & 44 \\
\hline 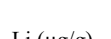 & Surface & 37.5 & 38.7 & 9.3 & 221.2 & 23 & 30 & 38 & 43 \\
\hline $\mathrm{Ll}(\mu \mathrm{g} / \mathrm{g})$ & Deep & 37.4 & 37.9 & 11.8 & 91.1 & 21 & 29 & 37 & 43 \\
\hline$M e$ & Surface & 997 & 1110 & 88 & 9721 & 425 & 569 & 725 & 825 \\
\hline 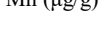 & Deep & 962 & 1053 & 89 & 3020 & 423 & 562 & 728 & 842 \\
\hline$M$ & Surface & 1.03 & 1.17 & 0.15 & 14.76 & 0.5 & 0.7 & 1.1 & 1.4 \\
\hline $1010(\mu g / g)$ & Deep & 1.05 & 1.19 & 0.33 & 4.86 & 0.5 & 0.7 & 1 & 1.3 \\
\hline 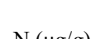 & Surface & 1700 & 1903 & 315 & 7396 & 343 & 707 & 1169 & 1540 \\
\hline iv & Deep & 824 & 900 & 315 & 2265 & 217 & 399 & 683 & 888 \\
\hline & Surface & 20.40 & 21.02 & 9.20 & 70.30 & 10 & 13 & 16 & 18 \\
\hline & Deep & 20.19 & 20.90 & 11.41 & 56.10 & 9 & 12 & 16 & 19 \\
\hline
\end{tabular}




\begin{tabular}{|c|c|c|c|c|c|c|c|c|c|}
\hline \multirow{2}{*}{$\mathrm{Ni}(\mu \mathrm{g} / \mathrm{g})$} & Surface & 51.1 & 57.9 & 3.7 & 361.1 & 16 & 24 & 31 & 36 \\
\hline & Deep & 57.7 & 61.0 & 18.8 & 175.9 & 15 & 22 & 31 & 36 \\
\hline \multirow{2}{*}{$\mathrm{P}(\mu \mathrm{g} / \mathrm{g})$} & Surface & 820 & 891 & 321 & 3424 & 411 & 570 & 748 & 869 \\
\hline & Deep & 537 & 592 & 219 & 1707 & 341 & 488 & 635 & 724 \\
\hline \multirow{2}{*}{$\mathrm{Pb}(\mu \mathrm{g} / \mathrm{g})$} & Surface & 33.7 & 45.2 & 4.4 & 2106.4 & 18 & 22 & 28 & 34 \\
\hline & Deep & 30.7 & 46.0 & 10.0 & 3323.3 & 16 & 21 & 26 & 32 \\
\hline \multirow{2}{*}{$\mathrm{Rb}(\mu \mathrm{g} / \mathrm{g})$} & Surface & 131.5 & 128.9 & 19.6 & 345.3 & 80 & 96 & 115 & 130 \\
\hline & Deep & 137.2 & 135.7 & 41.9 & 276.9 & 78 & 96 & 117 & 134 \\
\hline \multirow{2}{*}{$\mathrm{S}(\mu \mathrm{g} / \mathrm{g})$} & Surface & 272 & 303 & 15 & 2894 & 156 & 245 & 430 & 757 \\
\hline & Deep & 127 & 144 & 53 & 772 & 97 & 166 & 329 & 578 \\
\hline \multirow{2}{*}{$\mathrm{Sb}(\mu \mathrm{g} / \mathrm{g})$} & Surface & 1.80 & 3.56 & 0.03 & 145.46 & 0.47 & 0.73 & 1.08 & 1.38 \\
\hline & Deep & 1.70 & 3.03 & 0.24 & 32.35 & 0.43 & 0.67 & 1.03 & 1.31 \\
\hline \multirow{2}{*}{$\mathrm{Sc}(\mu \mathrm{g} / \mathrm{g})$} & Surface & 17.1 & 18.7 & 4.1 & 48.7 & 7 & 10 & 12 & 13 \\
\hline & Deep & 18.8 & 20.1 & 7.5 & 43.7 & 7 & 9 & 12 & 13 \\
\hline \multirow{2}{*}{$\operatorname{Se}(\mu \mathrm{g} / \mathrm{g})$} & Surface & 0.33 & 0.35 & 0.03 & 1.47 & 0.11 & 0.17 & 0.27 & 0.35 \\
\hline & Deep & 0.29 & 0.30 & 0.05 & 1.17 & 0.08 & 0.13 & 0.21 & 0.27 \\
\hline \multirow{2}{*}{$\mathrm{Sn}(\mu \mathrm{g} / \mathrm{g})$} & Surface & 4.07 & 4.36 & 1.19 & 89.64 & 2 & 3 & 4 & 5 \\
\hline & Deep & 4.04 & 4.20 & 1.80 & 21.21 & 2 & 3 & 3 & 4 \\
\hline \multirow{2}{*}{$\operatorname{Sr}(\mu \mathrm{g} / \mathrm{g})$} & Surface & 62 & 75 & 17 & 415 & 117 & 197 & 261 & 301 \\
\hline & Deep & 63 & 73 & 16 & 323 & 116 & 197 & 264 & 310 \\
\hline \multirow{2}{*}{$\operatorname{Th}(\mu \mathrm{g} / \mathrm{g})$} & Surface & 16.17 & 16.37 & 2.90 & 59.26 & 8 & 11 & 13 & 15 \\
\hline & Deep & 15.69 & 16.17 & 6.76 & 56.99 & 8 & 10 & 13 & 15 \\
\hline \multirow{2}{*}{$\mathrm{Ti}(\mu \mathrm{g} / \mathrm{g})$} & Surface & 6087 & 6464 & 2641 & 15932 & 2763 & 3498 & 4171 & 4611 \\
\hline & Deep & 5943 & 6353 & 3050 & 18382 & 2582 & 3406 & 4191 & 4662 \\
\hline \multirow{2}{*}{$\mathrm{Tl}(\mu \mathrm{g} / \mathrm{g})$} & Surface & 0.84 & 0.90 & 0.15 & 6.56 & 0.5 & 0.6 & 0.7 & 0.8 \\
\hline & Deep & 0.86 & 0.94 & 0.29 & 5.91 & 0.5 & 0.6 & 0.8 & 0.9 \\
\hline \multirow{2}{*}{$\mathrm{U}(\mu \mathrm{g} / \mathrm{g})$} & Surface & 3.01 & 3.19 & 0.39 & 14.11 & 2 & 2.5 & 3.2 & 3.8 \\
\hline & Deep & 3.08 & 3.26 & 1.21 & 13.58 & 1.8 & 2.4 & 3.1 & 3.7 \\
\hline \multirow{2}{*}{$\mathrm{V}(\mu \mathrm{g} / \mathrm{g})$} & Surface & 134.7 & 147.4 & 32.3 & 343.2 & 51 & 70 & 88 & 100 \\
\hline & Deep & 141.9 & 153.4 & 64.6 & 318.0 & 48 & 67 & 88 & 100 \\
\hline & Surface & 2.0 & 2.5 & 0.4 & 123.2 & 1.2 & 1.6 & 2 & 2.5 \\
\hline ( & Deep & 2.1 & 2.6 & 0.8 & 32.6 & 1.1 & 1.5 & 2 & 2.5 \\
\hline & Surface & 32.9 & 34.5 & 14.1 & 93.0 & 19 & 24 & 28 & 30 \\
\hline $1(\mu g)$ & Deep & 33.5 & 35.9 & 15.4 & 126.1 & 18 & 23 & 27 & 30 \\
\hline $7 n(-\sigma)$ & Surface & 100.4 & 114.8 & 28.0 & 1943.0 & 48 & 66 & 84 & 95 \\
\hline (2) & Deep & 100.2 & 115.5 & 34.6 & 1073.4 & 43 & 60 & 79 & 99 \\
\hline & Surface & 246 & 248 & 95 & 594 & 170 & 230 & 288 & 321 \\
\hline 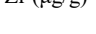 & Deep & 232 & 236 & 119 & 428 & 157 & 215 & 279 & 315 \\
\hline $\mathrm{SiO}_{2}$ & Surface & 61.1 & 61.0 & 37.2 & 84.2 & 61.2 & 66.7 & 72 & 75.1 \\
\hline$(w t \%)$ & Deep & 59.7 & 59.5 & 42.8 & 80.9 & 62.5 & 67.9 & 72.9 & 75.7 \\
\hline $\mathrm{Al}_{2} \mathrm{O}_{3}$ & Surface & 16.5 & 16.6 & 8.3 & 26.1 & 10.3 & 11.9 & 13.3 & 14.1 \\
\hline (wt.\%) & Deep & 18.3 & 18.3 & 11.0 & 26.0 & 10.1 & 11.9 & 13.4 & 14.2 \\
\hline $\mathrm{Fe}_{2} \mathrm{O}_{3 \text { Total }}$ & Surface & 7.33 & 7.76 & 1.97 & 16.29 & 3.2 & 4.2 & 5.3 & 5.9 \\
\hline (wt.\%) & Deep & 8.05 & 8.34 & 3.38 & 15.55 & 3 & 4.1 & 5.2 & 5.8 \\
\hline $\mathrm{MgO}$ & Surface & 1.11 & 1.44 & 0.26 & 11.22 & 0.9 & 1.43 & 2.2 & 2.65 \\
\hline (wt.\%) & Deep & 1.28 & 1.56 & 0.38 & 9.21 & 0.86 & 1.36 & 2.05 & 2.47 \\
\hline $\mathrm{CaO}$ & Surface & 0.76 & 1.60 & 0.10 & 18.30 & 1.12 & 2.74 & 6.08 & 7.79 \\
\hline (wt.\%) & Deep & 0.62 & 1.66 & 0.08 & 15.87 & 1.02 & 2.57 & 5.87 & 7.61 \\
\hline $\mathrm{Na}_{2} \mathrm{O}$ & Surface & 0.15 & 0.27 & 0.05 & 3.25 & 1.06 & 1.75 & 2.29 & 2.64 \\
\hline (wt.\%) & Deep & 0.17 & 0.31 & 0.05 & 2.13 & 1.05 & 1.81 & 2.38 & 2.76 \\
\hline $\mathrm{K}_{2} \mathrm{O}$ & Surface & 2.35 & 2.34 & 0.59 & 6.29 & 2.03 & 2.36 & 2.74 & 2.97 \\
\hline (wt.\%) & Deep & 2.56 & 2.54 & 0.69 & 4.80 & 2.03 & 2.36 & 2.79 & 3.06 \\
\hline $\mathrm{C}_{\text {Orgonic }}$ & Surface & 1.53 & 1.74 & 0.36 & 7.94 & 0.3 & 0.6 & 1.1 & 1.5 \\
\hline (wt.\%) & Deep & 0.59 & 0.68 & 0.05 & 3.19 & 0.2 & 0.3 & 0.5 & 0.8 \\
\hline $\mathrm{C}_{\text {Total }}$ & Surface & 1.82 & 2.12 & 0.31 & 11.33 & 0.8 & 1.3 & 2 & 2.5 \\
\hline (wt.\%) & Deep & 0.74 & 0.96 & 0.21 & 6.02 & 0.4 & 0.9 & 1.7 & 2.1 \\
\hline$U$ & Surface & 6.46 & 6.45 & 4.13 & 8.33 & 7 & 8 & 8.3 & 8.4 \\
\hline & Deep & 6.57 & 6.56 & 4.32 & 8.34 & 7.4 & 8.1 & 8.4 & 8.5 \\
\hline
\end{tabular}


824 Table 2 Statistical comparison of Baoshan river sediment data set with Regional

825 Geochemistry-National Reconnaissance (RGNR) data set.

\begin{tabular}{|c|c|c|c|c|c|c|}
\hline \multirow[b]{2}{*}{ Elements } & \multicolumn{4}{|c|}{ This study } & \multirow{2}{*}{$\begin{array}{c}\text { China Data (Shi et al., 2016) } \\
\text { Median }\end{array}$} & \multirow{2}{*}{$\frac{\text { SW China data (Shi et al., 2016) }}{\text { Median }}$} \\
\hline & Median & Mean & Min & Max & & \\
\hline $\mathrm{Ag}(\mathrm{ng} / \mathrm{g})$ & 73 & 102 & 20 & 5204 & 69 & 110 \\
\hline As $(\mu \mathrm{g} / \mathrm{g})$ & 15.2 & 21.5 & 0.7 & 615.6 & 8 & 9.9 \\
\hline $\mathrm{Au}(\mathrm{ng} / \mathrm{g})$ & 1.1 & 1.69 & 0.1 & 70 & 1.1 & 2.1 \\
\hline $\mathrm{B}(\mu \mathrm{g} / \mathrm{g})$ & 60 & 63 & 8 & 423 & 41 & 52 \\
\hline $\mathrm{Ba}(\mu \mathrm{g} / \mathrm{g})$ & 333 & 382 & 80 & 2986 & 474 & 575 \\
\hline $\mathrm{Be}(\mu \mathrm{g} / \mathrm{g})$ & 2.1 & 2.16 & 0.1 & 8.5 & 2 & 2.2 \\
\hline $\mathrm{Bi}(\mu \mathrm{g} / \mathrm{g})$ & 0.3 & 0.4 & 0.03 & 12.8 & 0.3 & 0.42 \\
\hline $\mathrm{Cd}(\mathrm{ng} / \mathrm{g})$ & 200 & 395 & 10 & 56700 & 110 & 140 \\
\hline Co $(\mu \mathrm{g} / \mathrm{g})$ & 24.1 & 26 & 5.7 & 69.5 & 11 & 11 \\
\hline $\mathrm{Cr}(\mu \mathrm{g} / \mathrm{g})$ & 98 & 114 & 9 & 607 & 54 & 74 \\
\hline $\mathrm{Cu}(\mu \mathrm{g} / \mathrm{g})$ & 39 & 49 & 2 & 1735 & 20 & 26 \\
\hline $\mathrm{F}(\mu \mathrm{g} / \mathrm{g})$ & 586 & 664 & 170 & 2170 & 460 & 495 \\
\hline $\mathrm{Hg}(\mathrm{ng} / \mathrm{g})$ & 84 & 237 & 9 & 126600 & 27 & 122 \\
\hline $\mathrm{La}(\mu \mathrm{g} / \mathrm{g})$ & 41 & 42 & 9 & 131 & 36 & 42 \\
\hline $\mathrm{Li}(\mu \mathrm{g} / \mathrm{g})$ & 32 & 32 & 7 & 100 & 30 & 35 \\
\hline $\operatorname{Mn}(\mu \mathrm{g} / \mathrm{g})$ & 1062 & 1136 & 134 & 3758 & 622 & 640 \\
\hline $\mathrm{Mo}(\mu \mathrm{g} / \mathrm{g})$ & 0.8 & 0.9 & 0.1 & 15 & 0.7 & 0.9 \\
\hline $\mathrm{Nb}(\mu \mathrm{g} / \mathrm{g})$ & 17 & 18 & 3 & 136 & 15 & 17 \\
\hline $\mathrm{Ni}(\mu \mathrm{g} / \mathrm{g})$ & 49 & 55 & 5 & 814 & 22 & 29 \\
\hline $\mathrm{P}(\mu \mathrm{g} / \mathrm{g})$ & 561 & 630 & 182 & 7636 & 535 & 610 \\
\hline $\mathrm{Pb}(\mu \mathrm{g} / \mathrm{g})$ & 27 & 95 & 5 & 39300 & 22 & 31 \\
\hline $\mathrm{Sb}(\mu \mathrm{g} / \mathrm{g})$ & 1.6 & 3.21 & 0.1 & 77.7 & 0.6 & 1.35 \\
\hline $\mathrm{Sn}(\mu \mathrm{g} / \mathrm{g})$ & 3.2 & 3.64 & 0.1 & 60 & 2.7 & 4.4 \\
\hline $\mathrm{Sr}(\mu \mathrm{g} / \mathrm{g})$ & 68 & 80 & 4 & 696 & 129 & 165 \\
\hline $\operatorname{Th}(\mu \mathrm{g} / \mathrm{g})$ & 11.3 & 12 & 2.9 & 157.2 & 11 & 13 \\
\hline $\operatorname{Ti}(\mu \mathrm{g} / \mathrm{g})$ & 5444 & 5872 & 362 & 31613 & 3881 & 4450 \\
\hline $\mathrm{U}(\mu \mathrm{g} / \mathrm{g})$ & 2.4 & 2.607 & 0.5 & 23.9 & 2.2 & 2.2 \\
\hline $\mathrm{V}(\mu \mathrm{g} / \mathrm{g})$ & 125 & 137 & 34 & 434 & 75 & 88 \\
\hline $\mathrm{W}(\mu \mathrm{g} / \mathrm{g})$ & 1.9 & 2.1 & 0.2 & 45 & 1.6 & 2.4 \\
\hline $\mathrm{Y}(\mu \mathrm{g} / \mathrm{g})$ & 27 & 29 & 10 & 224 & 24 & 28 \\
\hline $\mathrm{Zn}(\mu \mathrm{g} / \mathrm{g})$ & 86 & 108 & 6 & 4747 & 65 & 80 \\
\hline $\mathrm{Zr}(\mu \mathrm{g} / \mathrm{g})$ & 236 & 249 & 48 & 1776 & 248 & 275 \\
\hline $\mathrm{Al}_{2} \mathrm{O}_{3}(\mathrm{wt} . \%)$ & 14.2 & 14.25 & 4.2 & 26.4 & 12.8 & 12.8 \\
\hline $\mathrm{CaO}$ (wt.\%) & 2 & 3.58 & 0.03 & 28.9 & 1.3 & 3.5 \\
\hline $\mathrm{Fe}_{2} \mathrm{O}_{3 \text { Total }}(\mathrm{wt} . \%)$ & 6.8 & 7.2 & 0.1 & 17.2 & 4.3 & 4.7 \\
\hline $\mathrm{K}_{2} \mathrm{O}$ (wt.\%) & 1.9 & 2.03 & 0.3 & 6.3 & 2.4 & 2.3 \\
\hline $\mathrm{MgO}$ (wt.\%) & 1.2 & 2.16 & 0.3 & 16.2 & 1.2 & 1.7 \\
\hline $\mathrm{Na}_{2} \mathrm{O}$ (wt.\%) & 0.3 & 0.38 & 0.05 & 3.7 & 1.3 & 1.5 \\
\hline $\mathrm{SiO}_{2}$ (wt.\%) & 58.7 & 58.91 & 16 & 90.9 & 65.5 & 63.9 \\
\hline
\end{tabular}


Fig. 1 Contour maps of altitude, average surface soil $(0 \mathrm{~cm})$ temperature, and annual rainfall for study area. (Altitude data, surface soil temperature data and rainfall data from National Earth System Science Data Sharing Infrastructure, National Science \& Technology Infrastructure of China.

831 (http://www.geodata.cn))
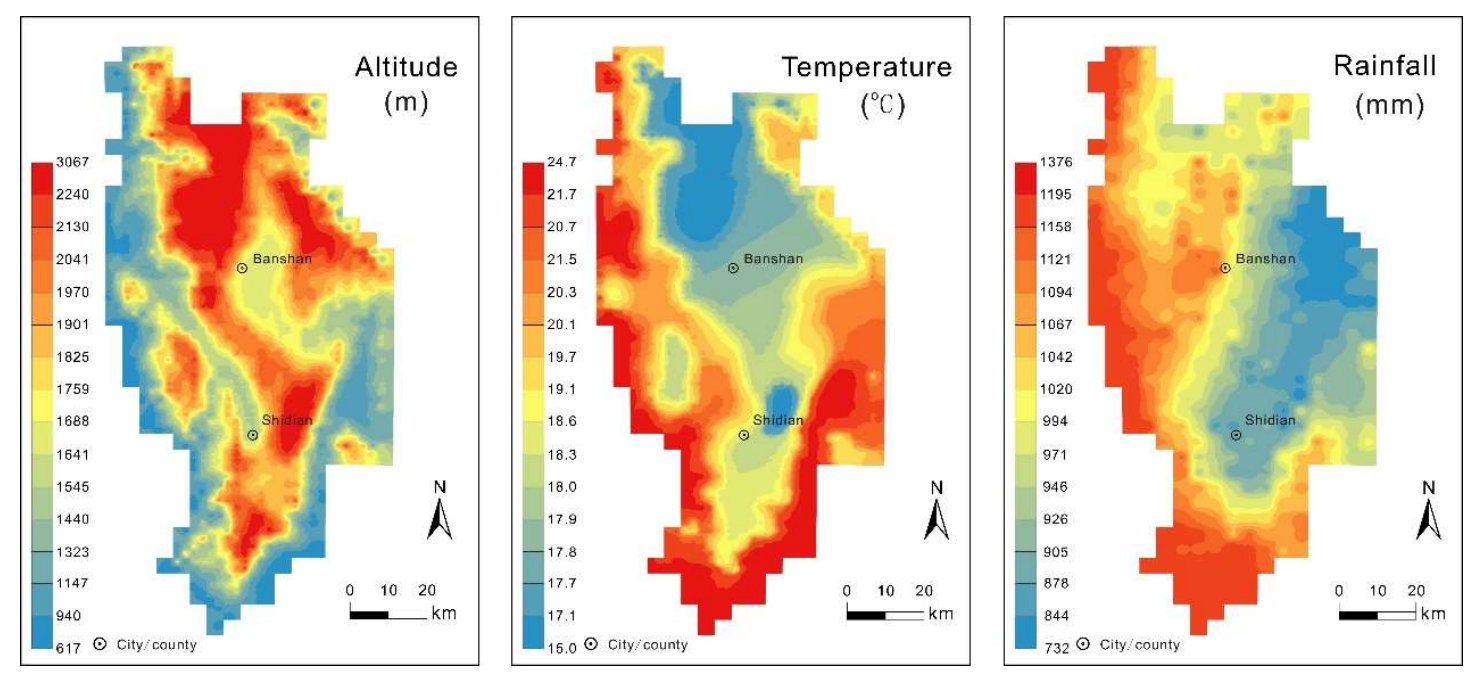


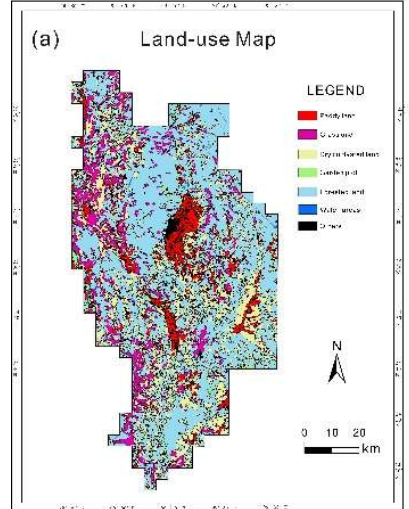

Fig. 2 General situation of study area. (a) Simplified land-use map of study area. (b, c) Simplified tectonic map of Yunnan Sanjiang area. (d) Simplified geological and mineral deposits map of study area (Geological map simplified from Yunnan geological and mineral development bureau regional geological survey team, 1981,1983,1986; Mineralization map from CGS mineral resources database http://geocloud.cgs.gov.cn).
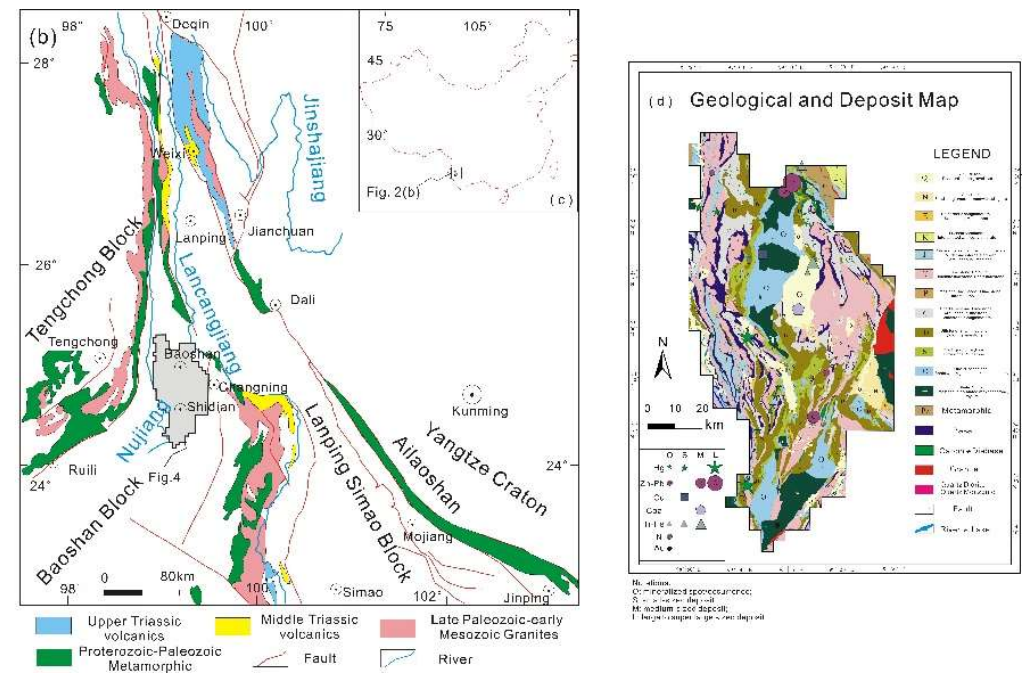

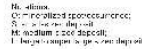



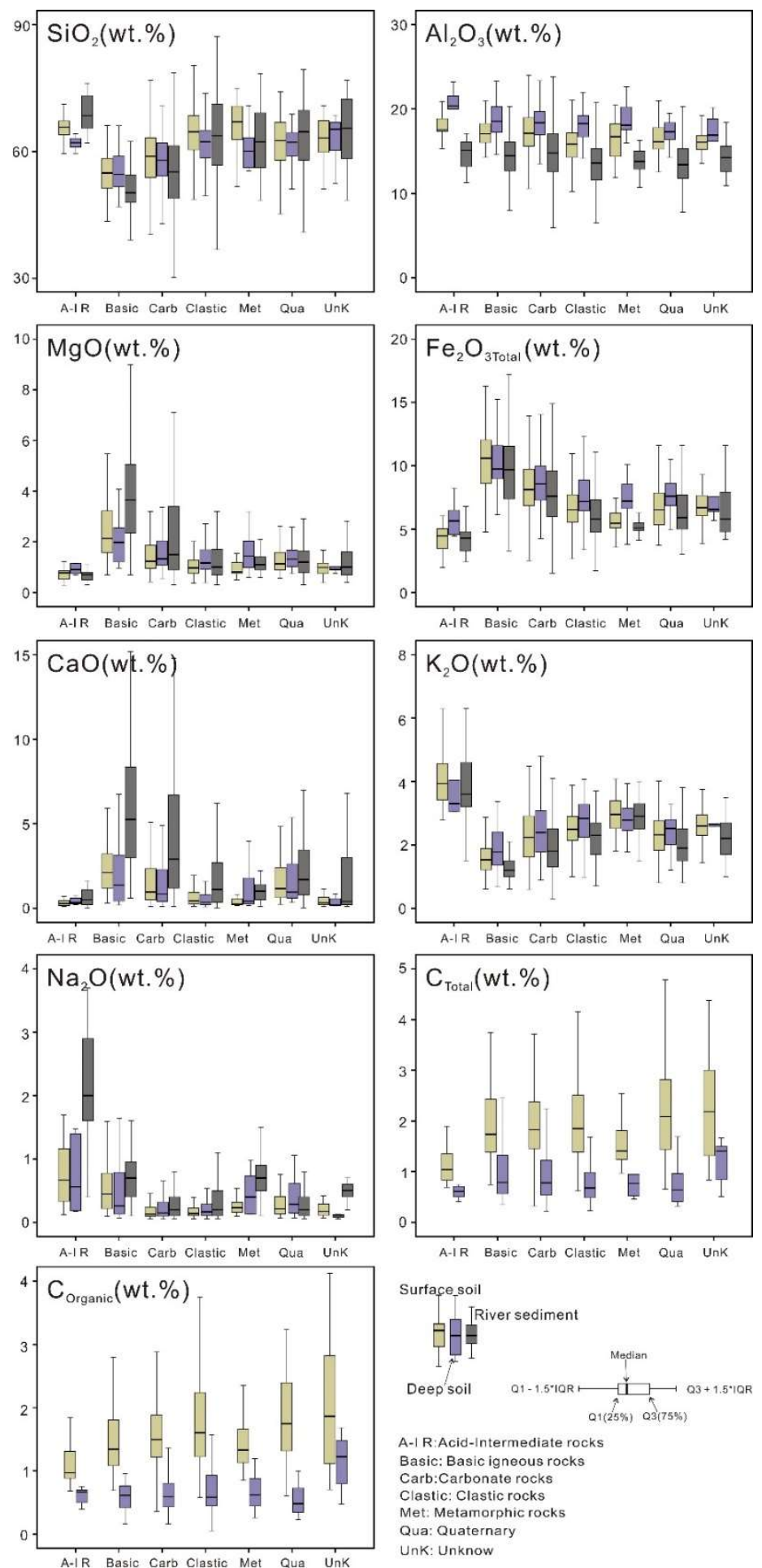

A-IR Basic Carb Clastic Met Qua UnK

Surface_soil

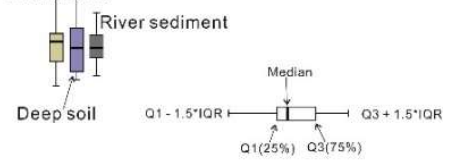

A-I R:Acid-Intermediate rocks

Basic: Basic igneous rocks

Carb.Carbonate rocks

Met: Metamorphic rocks

Qua: Quaternary

A-IR Basic Carb Clastic Met Qua UnK

UnK: Unknow 
Fig. 4 Major elements geochemical maps of surface soil, deep soil and river sediments in
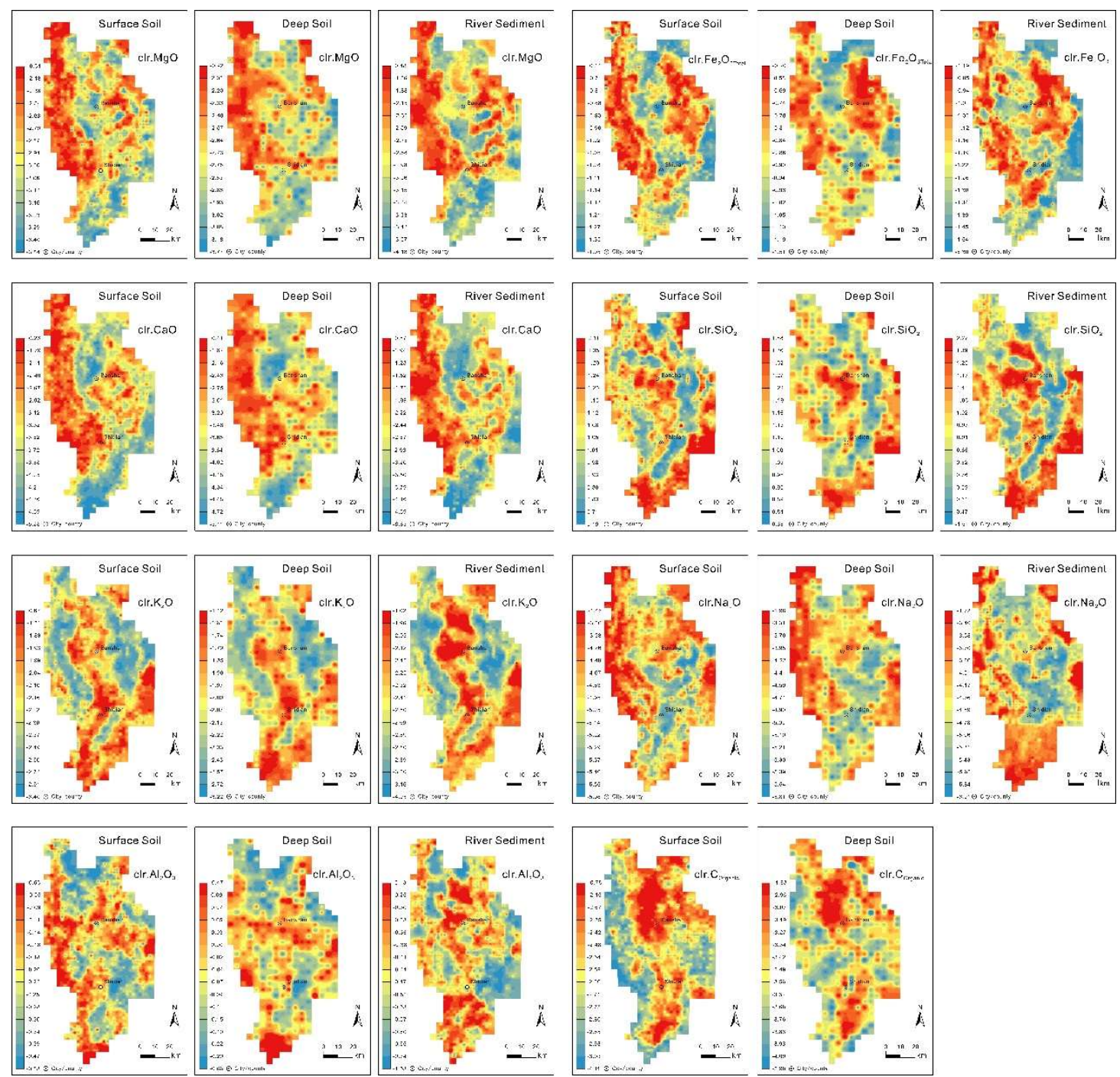
Fig. 5 Box plots of trace elements from soil and river sediments according to rock type groupings.
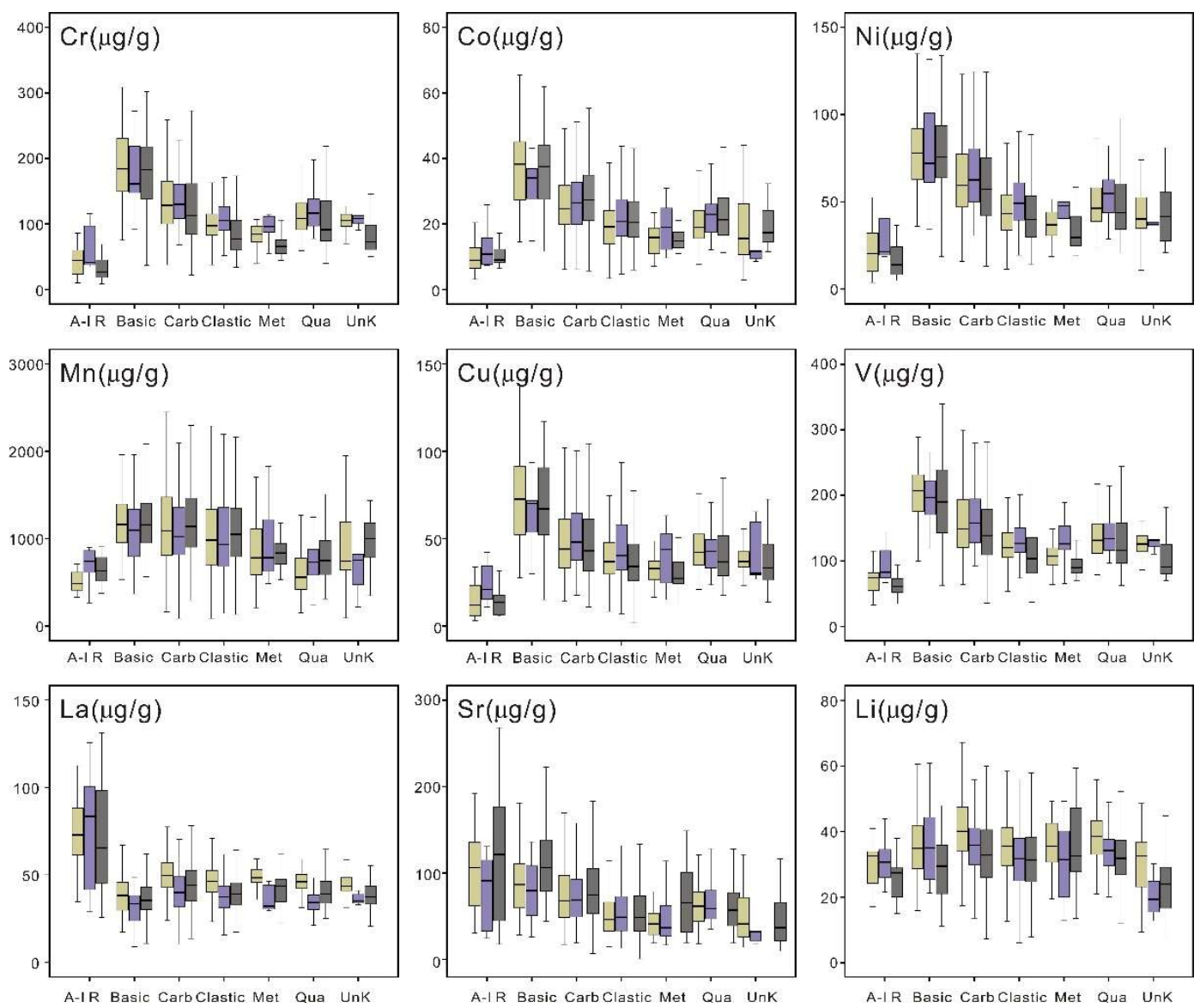
Fig. 6 Box plots of trace elements $\mathrm{Pb}, \mathrm{Zn}, \mathrm{Cd}, \mathrm{As}, \mathrm{Hg}$, Sb from soil and river sediments according to the relationship with mineralization.
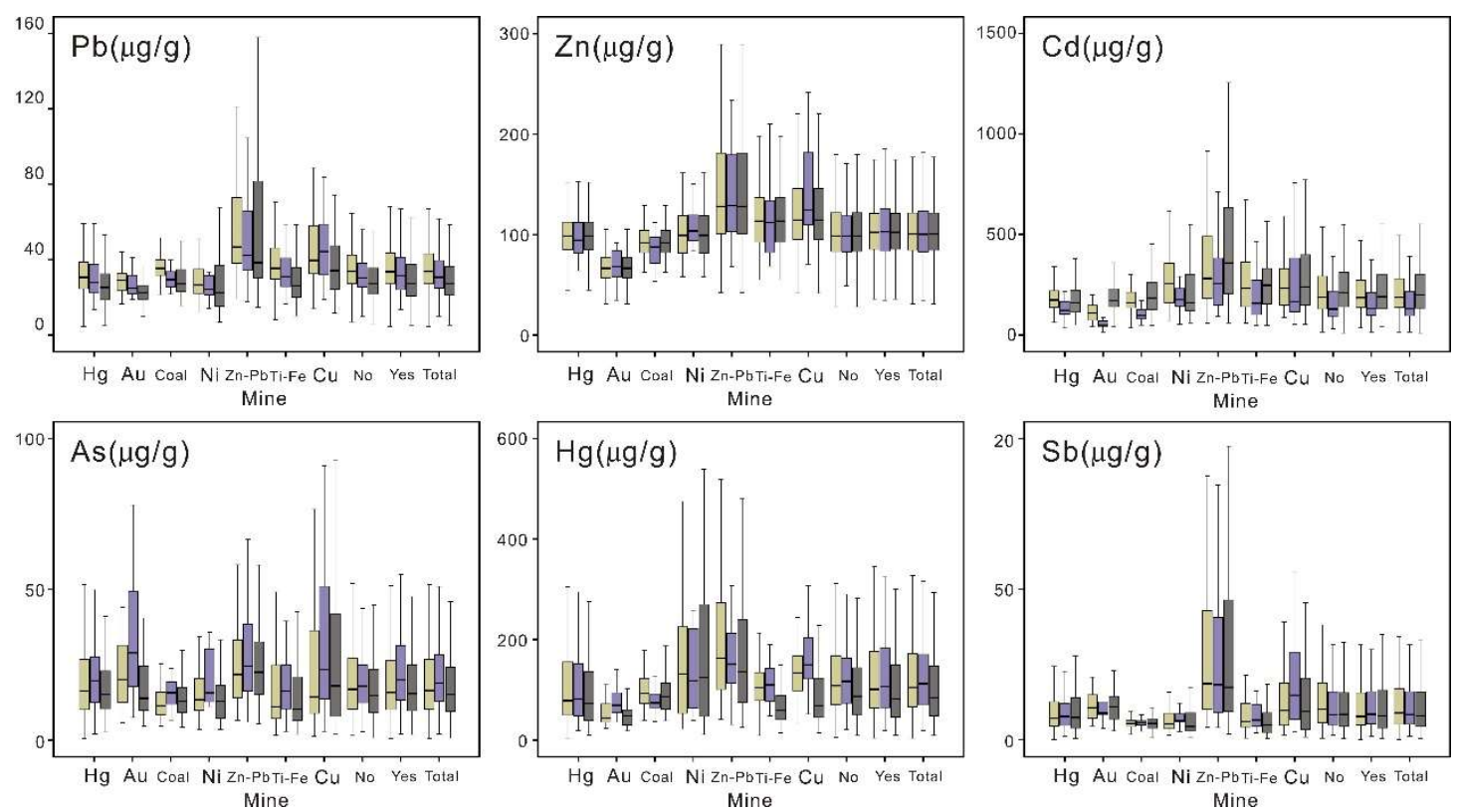
Fig. 7 Geochemical maps of trace elements in soil and river sediments. Mineralization occurrences plotted for comparison in $\mathrm{Pb}$ and $\mathrm{Hg}$ geochemical map.
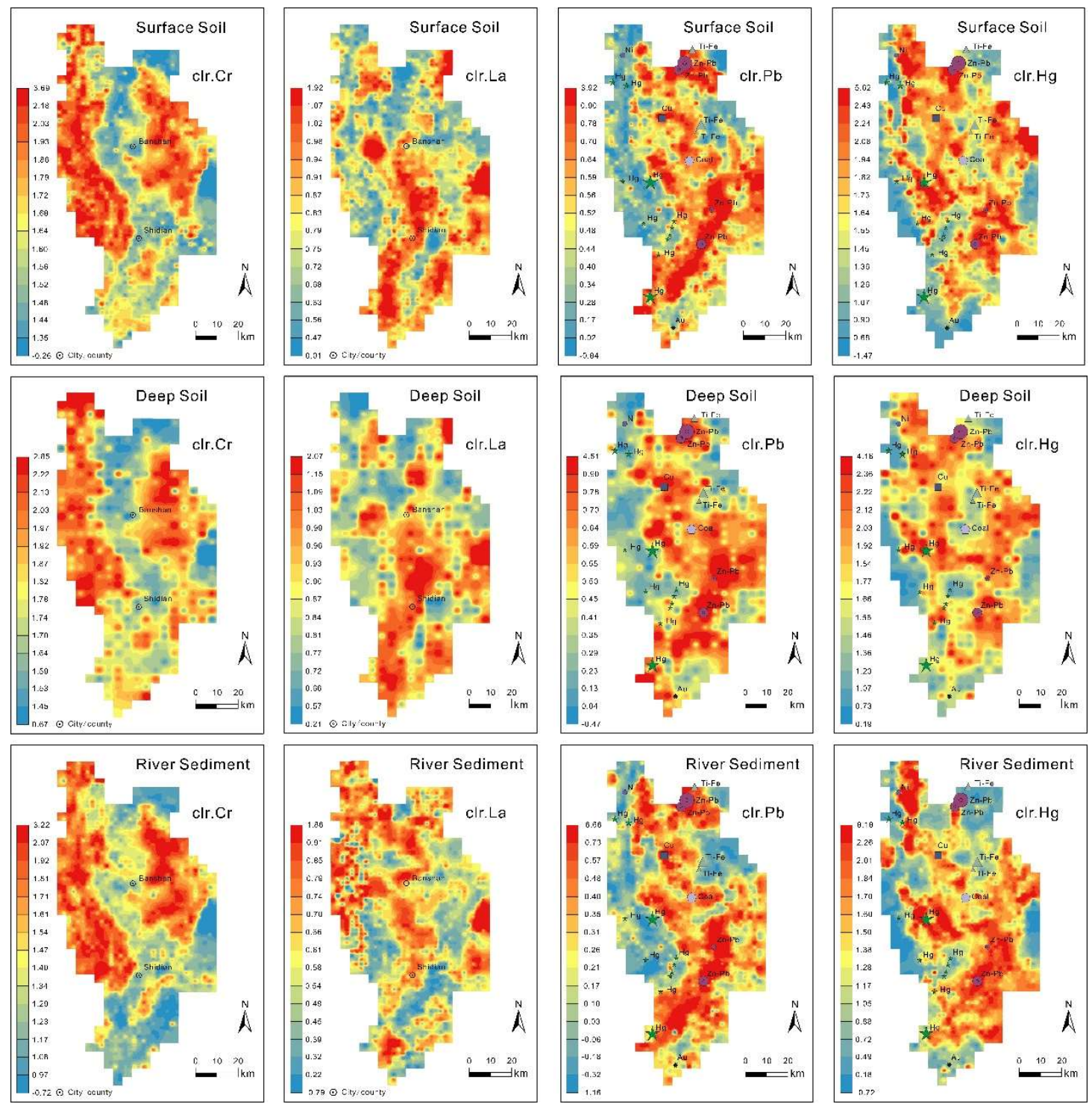
854

855

Fig. 8 Spatial distribution of PCs of surface soil. Geological, mineralization, altitude and landuse maps are presented for comparison.
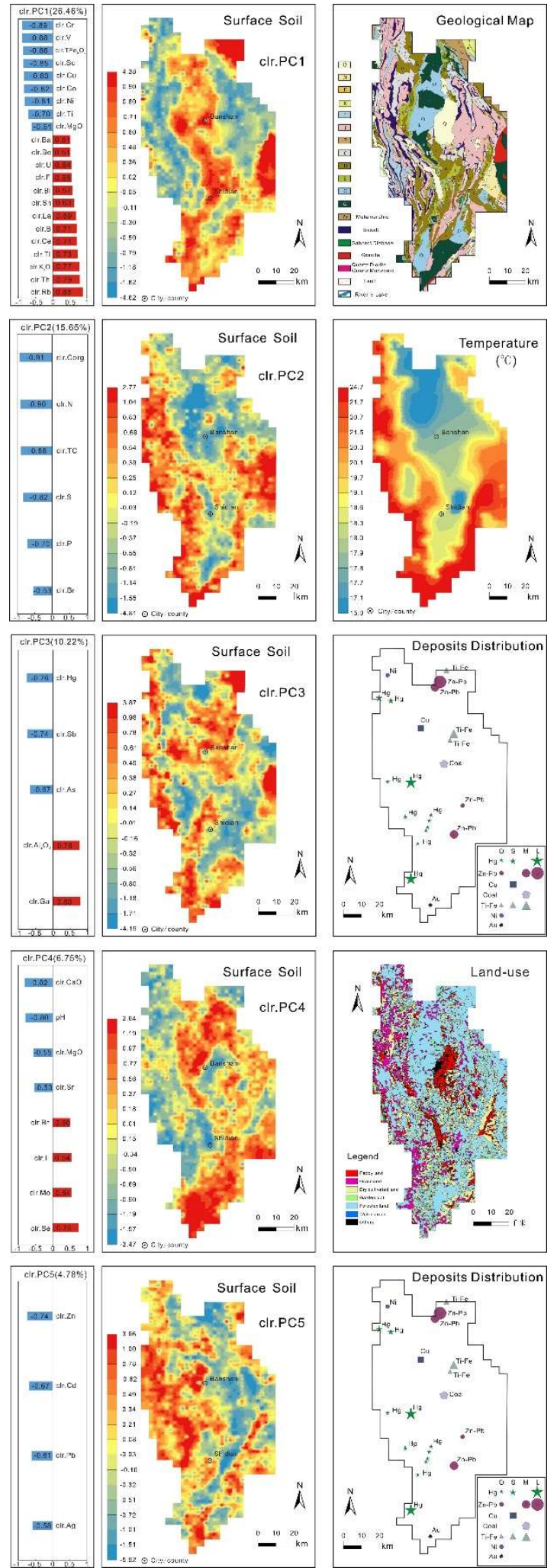

Detailed legend description of geological and deposits maps is showed Fig. 2d. 

use maps are presented for comparison.
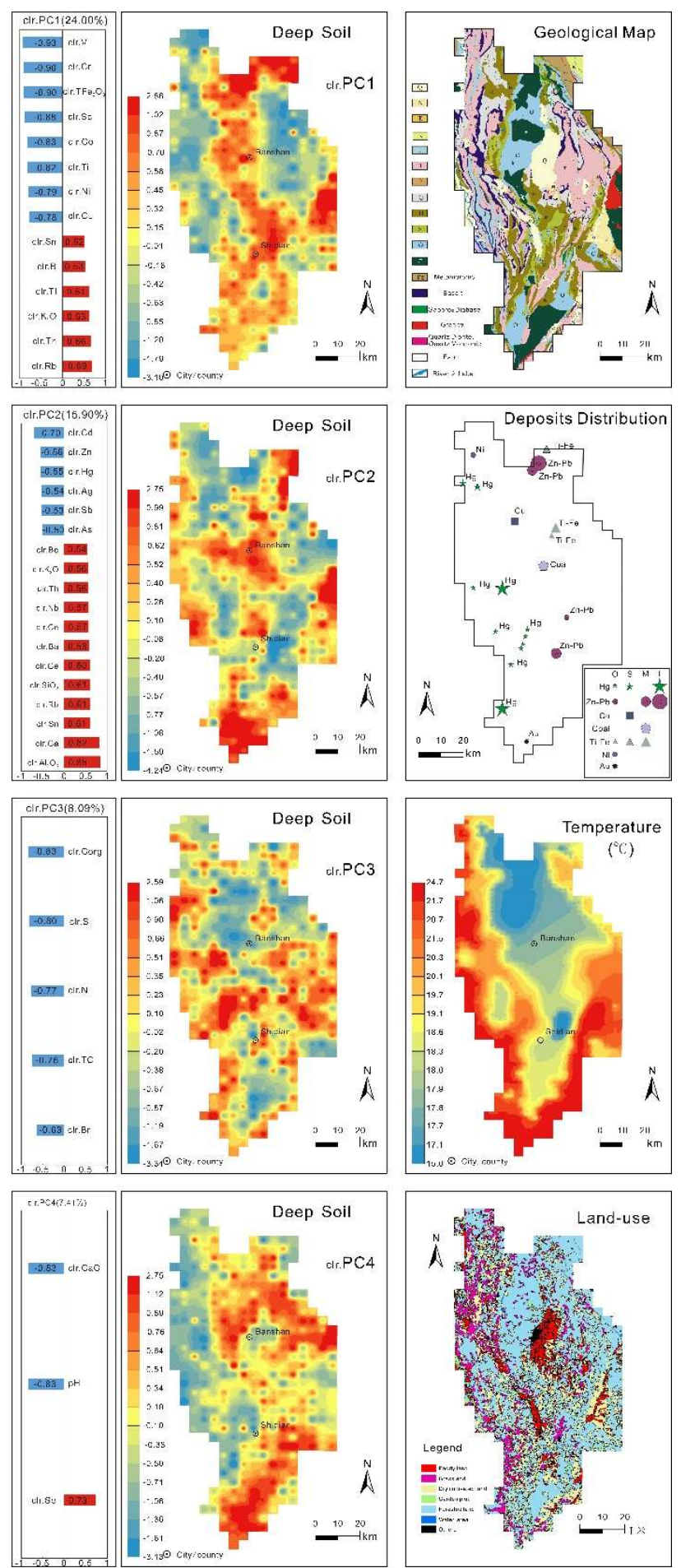

Detailed legend description of geological and deposits maps is showed Fig. 2d. 

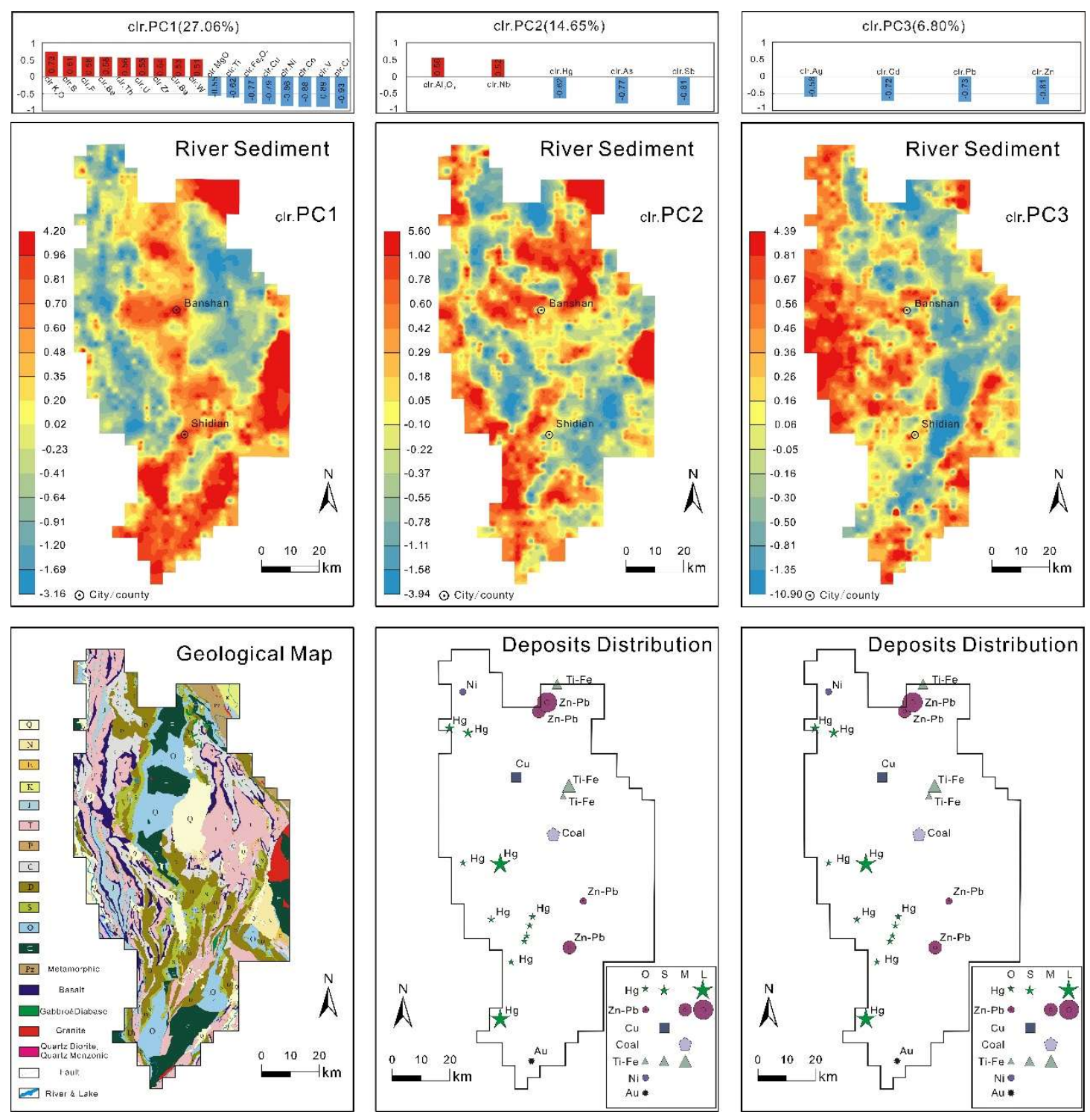

Detailed legend description of geological and deposits maps is showed Fig. 2d. 